\title{
La tecnología constructiva andalusí: obra encofrada y revestimientos en la arquitectura militar (ss. XI-XIII). El ejemplo de las torres
}

\section{Constructive technology of al-Ándalus: formwork and coating in military architecture (XI-XIII th). The example of the towers}

\author{
Samuel Márquez Bueno ${ }^{1}$ \\ Consejería de Educación de la Junta de Extremadura
}

A Pablo Quevedo Bueno, por estar siempre ahí, incluso en este artículo.

\section{RESUMEN}

Se plantea el estudio de las fábricas encofradas desde las taifas hasta los almohades, por considerarse tal lapso cronológico el período en el que se desarrolla y consolida la tecnología constructiva mediante tapiales. Para ello, se propone un recorrido evolutivo en torno a la puesta en obra de uno de los principales y omnipresentes elementos poliorcéticos: la torre de flanqueo.

Palabras clave: torre; tapial; taifas; almorávides; almohades.

\begin{abstract}
This article is about the formwork construction from Taifas to Almohads, as this is the chronological span in which the rammed earth technique is developed and consolidated. It proposes an evolutionary journey regarding the flanking towers, one of the main and ubiquitous poliorcetic elements.
\end{abstract}

Key words: tower; rammed earth; Taifas; Almoravids; Almohads.

Recibido: 14-09-2017. Aceptado: 22-11-2017. Publicado online: 14-11-2018

Cómo citar este artículo / Citation

Márquez Bueno, S. 2018: "La tecnología constructiva andalusí: obra encofrada y revestimientos en la arquitectura militar (ss. XI-XIII). El ejemplo de las torres", Arqueología de la Arquitectura, 15: e076. https://doi.org/10.3989/arq.arqt.2018.007

Copyright: (c) 2018 CSIC. Este es un artículo de acceso abierto distribuido bajo los términos de la licencia de uso y distribución Creative Commons Reconocimiento 4.0 Internacional (CC BY 4.0).

\section{INTRODUCCIÓN}

En la arquitectura militar andalusí, entre los siglos XI y XIII se producirá, en detrimento de los ciclos productivos de cantería, un espectacular desarrollo de las técnicas de albañilería vinculado a las nuevas circunstancias socioeconómicas y necesidades bélicas de los sucesores del califato omeya: reinos de taifas y dinastías africanas (Gurriarán 2014: 276-280). Entre tales procedimientos descollará el empleo generalizado de obra encofrada formalizada mediante tapiales, a la que se acabarán supeditando el resto de técnicas en las que habitualmente se usan materiales como mampostería y ladrillo. 
A pesar de que en los últimos veinte años se han producido grandes progresos en el conocimiento de la construcción mediante tapiales, la mayoría de los trabajos se han enfocado en aspectos tecnológicos generales, difusión geográfica y cronológica, o ensayos de análisis cronotipológicos ${ }^{2}$. En cualquier caso, la mayoría de estos estudios, cuando han abordado la cuestión de la puesta en obra, lo han hecho de una forma relativamente somera: describían con todo lujo de detalles la formalización de un encofrado genérico, pero solían obviar los aspectos concretos de puesta en obra en edificios masivos, tales como las fortificacio$n^{3}{ }^{3}$. En este artículo se pretende hacer una aportación, en ese sentido, mediante el análisis del proceso constructivo de las torres, desde la arqueología de la arquitectura; cuya elección se justifica por la variedad de soluciones tecnológicas necesarias para su erección. De este modo, en una torre será preciso plantear tanto cómo se resolverán las partes inferiores macizas, de gran volumetría; como paredes más delgadas en las cámaras y pretiles, o elementos mínimos como los merlones. Este estudio ha comportado un importante trabajo de campo realizado a través de las huellas que ha dejado el proceso edilicio sobre la superficie de las tapias, así como de su interior, únicamente accesible en estado de ruina parcial de la obra. Precisamente,

\footnotetext{
2 Por citar algunos ejemplos: López Martínez (1999) realizó un trabajo fundamental y pionero, ya clásico e imprescindible, en el que se detallan minuciosamente los elementos de un encofrado, y su disposición en distintas circunstancias constructivas. Gurriarán y Sáez (2002) ofrecen un amplio análisis desde varios puntos de vista: aspectos tecnológicos y tipológicos, implantación de la técnica en las distintas etapas históricas de al-Ándalus, e incluso cuestiones simbólicas. Márquez y Gurriarán (2003: 93-96; 2006: 4148; 2008: 117-121) hacen hincapié en cuestiones metodológicas relacionadas con construcciones masivas y análisis de soluciones de elementos específicos. Graciani y Tabales (2008) abordan un análisis cronotipológico desde diversos parámetros, aunque centrado en un área geográfica muy concreta. Soler (2009), igualmente sobre un entorno geográfico preciso, realiza un análisis del proceso constructivo focalizado en el cajón como módulo y su yuxtaposición con otros similares. Por su parte, Navarro y Jiménez (2011), desde la arqueología realizan un minucioso análisis de la construcción medieval en tapia, en la región de Murcia, pero con aspectos claramente extrapolables a la construcción andalusí, en general. Canivell y Graciani (2015) insisten de nuevo en el análisis cronotipológico desarrollado anteriormente por Graciani y Tabales, aunque desde una óptica más amplia en la que reconocen sin embargo las limitaciones del método, también sus bondades y utilidad, y la necesidad de complementarlo con otras técnicas de datación. Gil-Crespo y Maldonado-Ramos (2015) tratan de desarrollar una taxonomía constructiva abierta para establecer criterios cronotipológicos.

3 Afortunadamente, empiezan a ver la luz trabajos como los de Mileto y Vegas (2014), y López Osorio (2015), en el que precisamente se tratan esos aspectos de los que adolecían los anteriores estudios. Sin duda, la espectacular mejora en los conocimientos se ha debido a la actividad restauradora, de los últimos años, en la que se ha tendido a documentar exhaustivamente el edificio objeto de cada intervención.
}

estas circunstancias han condicionado profundamente el criterio de selección de las fortificaciones tratadas en este artículo. De hecho, una parte relevante de las indagaciones se realizó hace más de una década, antes de que la actividad restauradora ocultara la información que nos proporcionaron múltiples vestigios monumentales ${ }^{4}$. Este análisis directo sobre el elemento arquitectónico se ha complementado con el efectuado sobre concienzudos levantamientos planimétricos, de elaboración propia, en los que se han combinado diversas técnicas de restitución, incluyendo las más novedosas y precisas mediante nubes de puntos. A la hora de buscar un marco cronológico para los procesos analizados, se ha recurrido a todas las fuentes bibliográficas disponibles, sin perder de vista el problema de la fiabilidad de las mismas, dado la heterogeneidad de su calidad. Ante la disyuntiva en las contradicciones de dos o más fuentes, se han priorizado los criterios ofrecidos por la arqueología; aunque es necesario reconocer que hasta fechas muy recientes esta disciplina no ha sido capaz de establecer cronologías absolutas sino procesos de anteroposterioridad. Por todo ello, las hipótesis planteadas en este artículo, al menos desde el punto de vista de la adjudicación temporal precisa, pueden estar sujetas a revisión; aunque la correlación general pueda gozar de una mayor solidez. Finalmente, en un apartado específico se planteará la evolución de los tratamientos epidérmicos de la obra encofrada, desde las taifas hasta lo almohade 5 .

Por otra parte, conviene aclarar que no todas las obras tratadas han recibido las mismas atenciones por parte de los distintos autores, ni han contado con procesos analíticos uniformes. Lógicamente, esto ha influido en la calidad de sus respectivos desarrollos

\footnotetext{
4 En ese trabajo de campo estuvo profundamente implicado Pedro Gurriarán Daza, con el que tengo una importante deuda de gratitud, también por sus consejos tan pertinentes para este artículo. De hecho, parte del material gráfico originario fue ya publicado por nosotros, aunque en condiciones insuficientes. En Gurriarán y Márquez (2005: 69, Figs. 1-7) aparecen una serie de dibujos, en los que se describía el proceso edilicio de las torres taifa de Almería, pero a un tamaño excesivamente reducido y sin las oportunas explicaciones. Parte de ese material ha servido de base para la elaboración de la figura 4 del presente trabajo, tras su revisión y actualización. Algo parecido sucedió en Márquez y Gurriarán (2006: 43-44, Figs. 10 y 11), en que unos dibujos que muestran la erección de la parte maciza de unas torres, en este caso impresos a buen tamaño y convenientemente descritos, no tuvieron apenas repercusión por el carácter no venal de la propia publicación. De nuevo, parte de ese material ha sido revisado y rehecho para la figura $11 \mathrm{de}$ este artículo.

5 En esa parte, tengo que agradecer también la inestimable ayuda de Juan Antonio García Granados. Tampoco me olvido de Daniel Jiménez Maqueda, por sus certeras observaciones en el conjunto de este trabajo.
} 
historiográficos así como en la fiabilidad de las adscripciones cronológicas; cuestiones de las que se advertirá oportunamente a lo largo de este trabajo.

\section{SENTANDO LAS BASES: DESDE LA CONQUISTA HASTA LOS OMEYAS}

Según algunos autores, las más antiguas obras encofradas andalusíes de carácter militar de las que hay constancia, adjudicables a los años de la conquista peninsular y expediciones a las Galias, podrían documentarse en el recinto del Llano de Almatà, en Balaguer (Gurriarán y Sáez 2002: 593; García Biosca et al. 1998: 146). Por otra parte, en la fortaleza califal de Gormaz, rehecha en torno al 965, se ha registrado la presencia de una fase anterior erigida mediante tapias (Almagro 2008: 57, 69-74). Sin embargo, ninguno de los dos ejemplos puede proporcionarnos pista alguna sobre la tecnología constructiva, pues en el primer caso los vestigios terrosos están muy meteorizados y en el segundo no subsiste resto alguno.

Además, en los últimos tiempos se ha asistido a la "reclasificación" de las dos únicas fortalezas construidas masivamente mediante tapiales: El Vacar y Baños de la encina, tradicionalmente encuadradas como omeyas del s. X, que tras las últimas y comúnmente aceptadas tesis han pasado a ser consideradas ambas de época almoha$\mathrm{de}^{6}$. Esta nueva situación nos deja sin grandes referentes arqueológicos de obra encofrada para estos siglos iniciales $^{7}$. No obstante, en la cerca omeya de Almería se documentan torres de considerable tamaño así resueltas tecnológicamente, de las que se ha conservado la parte inferior de una de ellas (Gurriarán y Márquez 2005: 63, Lám. 2). Así pues, todo parece indicar que ya en la décima centuria se había desarrollado suficientemente la tecnología constructiva de obra encofrada como para hacer frente a obras de cierto calado. Sin embargo, los exiguos vestigios arqueológicos impiden conocer la formalización concreta de tales recursos.

\footnotetext{
6 En el caso de El Vacar, la tradicionalmente admitida cronología califal ha sido paulatinamente contestada en favor de una almohade. Así lo afirman con claridad Azuar et al. (1994: 493, 501) y posteriormente Córdoba (2004: 124-126) tras un conciso análisis del estado de la cuestión. A tal propuesta se sumarán sin reservas Márquez y Gurriarán (2008: 117-118). Finalmente, Azuar y Ferreira (2014: 401) zanjarán tanto este asunto como la revisión cronológica de Baños de la Encina, también a favor del período almohade; tras una revisión del estado de la cuestión y de las últimas intervenciones arqueológicas.

7 Gurriarán y Sáez (2002: 591-597) realizan una síntesis pionera sobre las obras encofradas en el emirato y califato omeya.
}

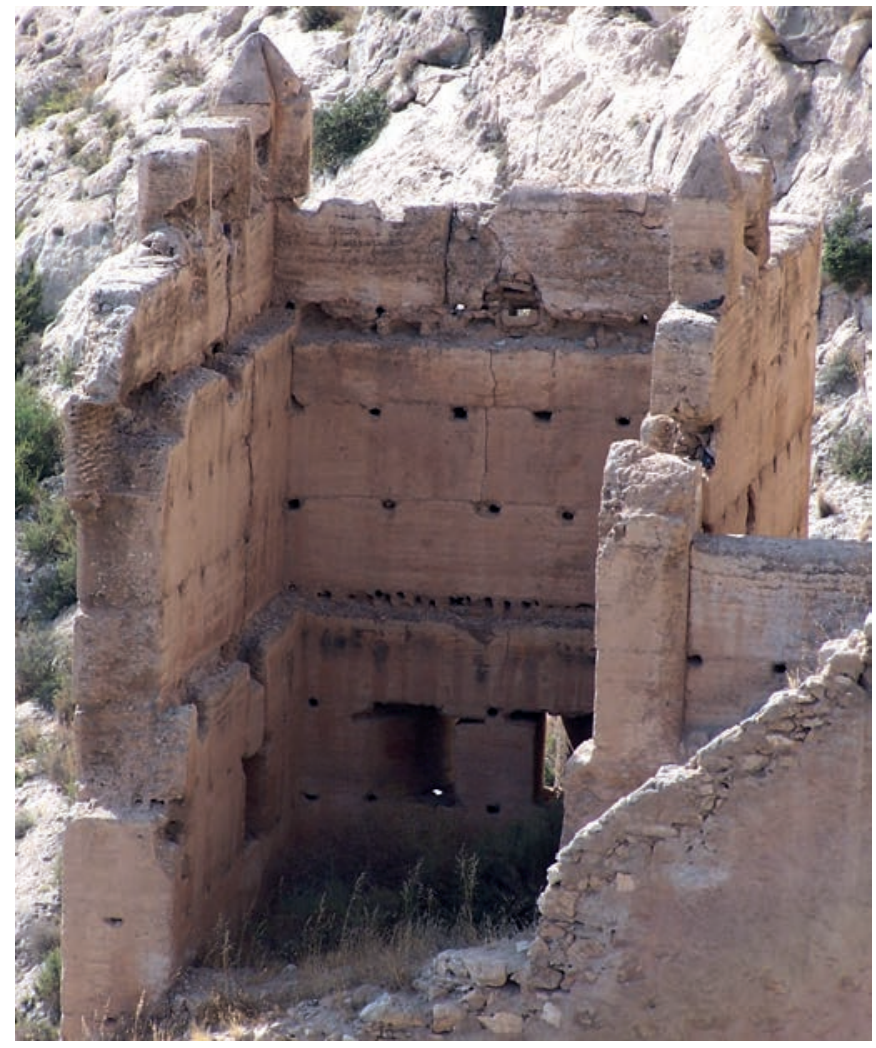

Figura 1. Vista desde el sureste de la torre 10 del tramo conocido como "Muralla de la Hoya", en la que se aprecian los vestigios de las cámaras superpuestas.

\section{LA DEFINICIÓN TECNOLÓGICA EN LAS TAIFAS}

La inicial pervivencia de la construcción en cantería bajo las taifas se verá restringida a obras puntuales, y de volumen discreto; pues ante la necesidad de hacer frente a edificaciones masivas se impondrán rápidamente las técnicas de albañilería. De este modo y citando ejemplos conocidos, se erigirán grandes fortificaciones de mampostería, en los casos de Valencia, la Alcazaba de Badajoz, y el recinto del palacio de Onda, en Castellón ${ }^{8}$; y de tapias en el caso de Almería, que trataré a continuación.

\footnotetext{
En las fases taifas de los recintos de Valencia, la Alcazaba de Badajoz, y del palacio de Onda; se ha documentado arqueológicamente la presencia de lienzos y torres semicirculares de mampostería. Léase respectivamente en Pascual y Martí (2002), Sánchez (2013: 43, 89) y Navarro (2012: 301-302). No obstante, debo a la amabilidad y generosidad de Julio Navarro Palazón, en calidad de excavador del yacimiento de Onda, la confirmación documental de que las torres del palacio fueron erigidas originariamente mediante tapias terrosas, siendo posteriormente forradas por mampostería.
} 

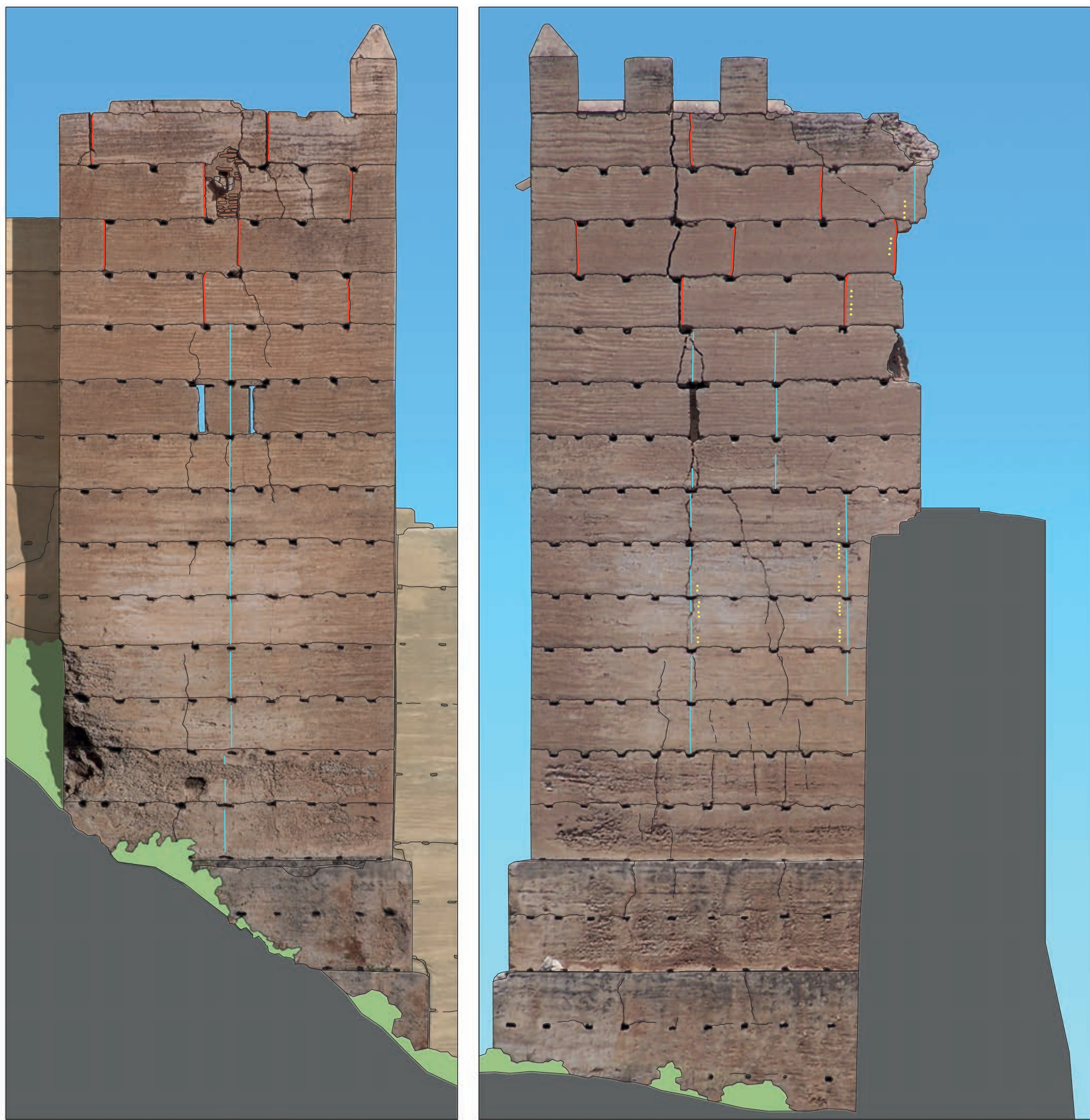

0 5 $10 \mathrm{~m}$

Figura 2. Alzado fotogramétrico de las caras noroeste y suroeste de la torre 10 de la "Muralla de la Hoya", realizado con la colaboración de Pedro Gurriarán Daza. Las rebabas de los tapiales se indican en azul, las juntas en rojo, y las huellas de las cabezas de los clavos en amarillo. 
No obstante, es necesario advertir que la tradicionalmente reconocida cronología taifa que sitúa la erección del arrabal oriental, objeto de mi atención, entre la segunda y tercera década del s. XI (Gurriarán y Márquez 2005: 64, 67-68), podría ser puesta en tela de juicio a falta de una confirmación arqueológica definitiva, aunque por ahora las excavaciones tienden a sustentar las tesis tradicionales ${ }^{9}$. Si bien es cierto que las fuentes mencionan la erección de ese y otros recintos urbanos bajo los gobiernos de Jayrān y Zuhayr, habría que preguntarse si los tramos de murallas conservados son realmente los que ordenaron levantar estos régulos. A favor de la opinión comúnmente admitida estaría el aparente carácter monofásico, los datos que hasta ahora ha proporcionado la arqueología, y un singular y relevante detalle como la sillería de tradición cordobesa de la poterna de San Cristóbal, aparejo vigente en las primeras taifas. En contra, la sorprendente madurez tecnológica y formal de las torres y lienzos del recinto, y otras menciones cronísticas que recogen posteriores intervenciones constructivas en las murallas de la ciu$\mathrm{dad}^{10}$. Según parece, las refacciones recogidas por las fuentes deben aludir a reparaciones puntuales y a la erección de un antemural, constatada en el subsuelo, por lo que no se plantean mayores objeciones a las tesis tradicionales.

Independientemente de estas cuestiones, la relativa buena conservación de algunas de sus torres ha permitido efectuar un concienzudo análisis de su proceso constructivo. Formalmente, se trata de torres cuadrangulares sobre zarpas, y macizas hasta las cámaras situadas por encima del nivel del adarve. Tales habitáculos se disponían por pares, uno sobre el otro, e iban cubiertos por forjados planos de madera conectados entre sí y con el terrado cimero mediante escaleras escamoteables (Fig. 1). El grosor de los muros iba disminuyendo escalonada y progresivamente de la cámara inferior a la superior y finalmente al pretil y merlatura del terrado; de modo que los sucesivos escalonamientos servían de apoyo a los respectivos forjados, reforzados además por parejas de vigas maestras. Únicamente el habitáculo inferior contaba

\footnotetext{
9 Gómez Muro (2003: 30-34) confirma la filiación taifa de la muralla y data una segunda línea defensiva, que es claramente el antemuro, en el primer cuarto del s. XII, en época almorávide. No obstante, no ofrece criterios claros de datación más allá de las relaciones de anteroposterioridad de las estructuras excavadas.

10 Gurriarán (En prensa) plantea la cuestión en estos términos, en una síntesis sobre la Almería islámica, que aun centrada en la etapa nazarí, hace un necesario y perspicaz recorrido por todo el período andalusí.
}

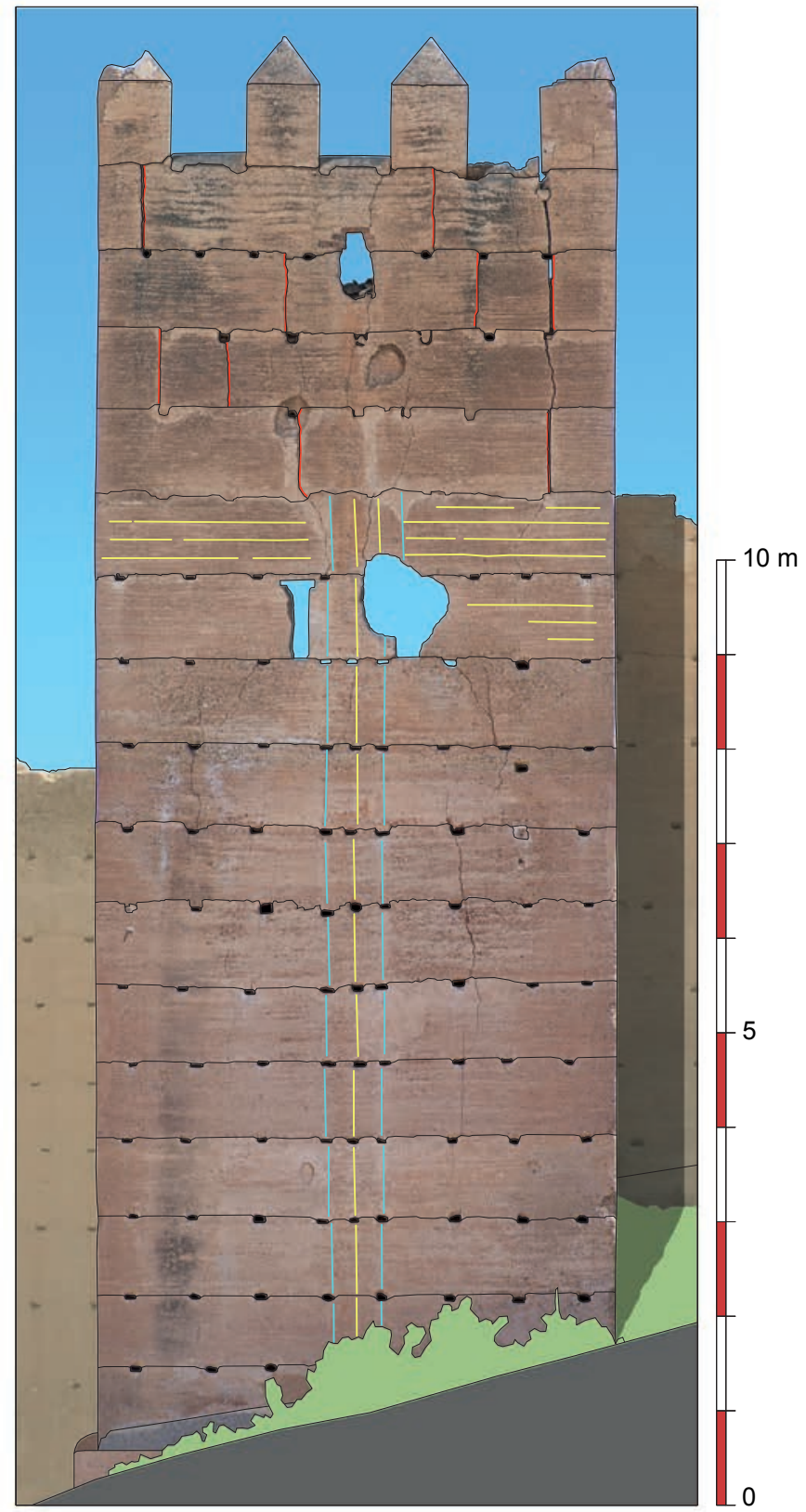

Figura 3. Alzado fotogramétrico de la cara norte de la torre 6 del tramo conocido como "Muralla de San Cristóbal", realizado con la colaboración de Pedro Gurriarán Daza. Las rebabas de los tapiales se indican en azul, las juntas en rojo, y las huellas de los tablones en amarillo.

con cuatro saeteras con derrame hacia el interior, dispuestas una en cada flanco y dos contiguas en la pared frontal. Finalmente, las zarpas se remataban por cuartos de caña, los tramos cimeros del pretil entre merlones por medias cañas, y los merlones por albardillas piramidales (Figs. 2, 3 y 4).

Aunque no es intención ni propósito de este trabajo definir cada uno de los elementos constitutivos 

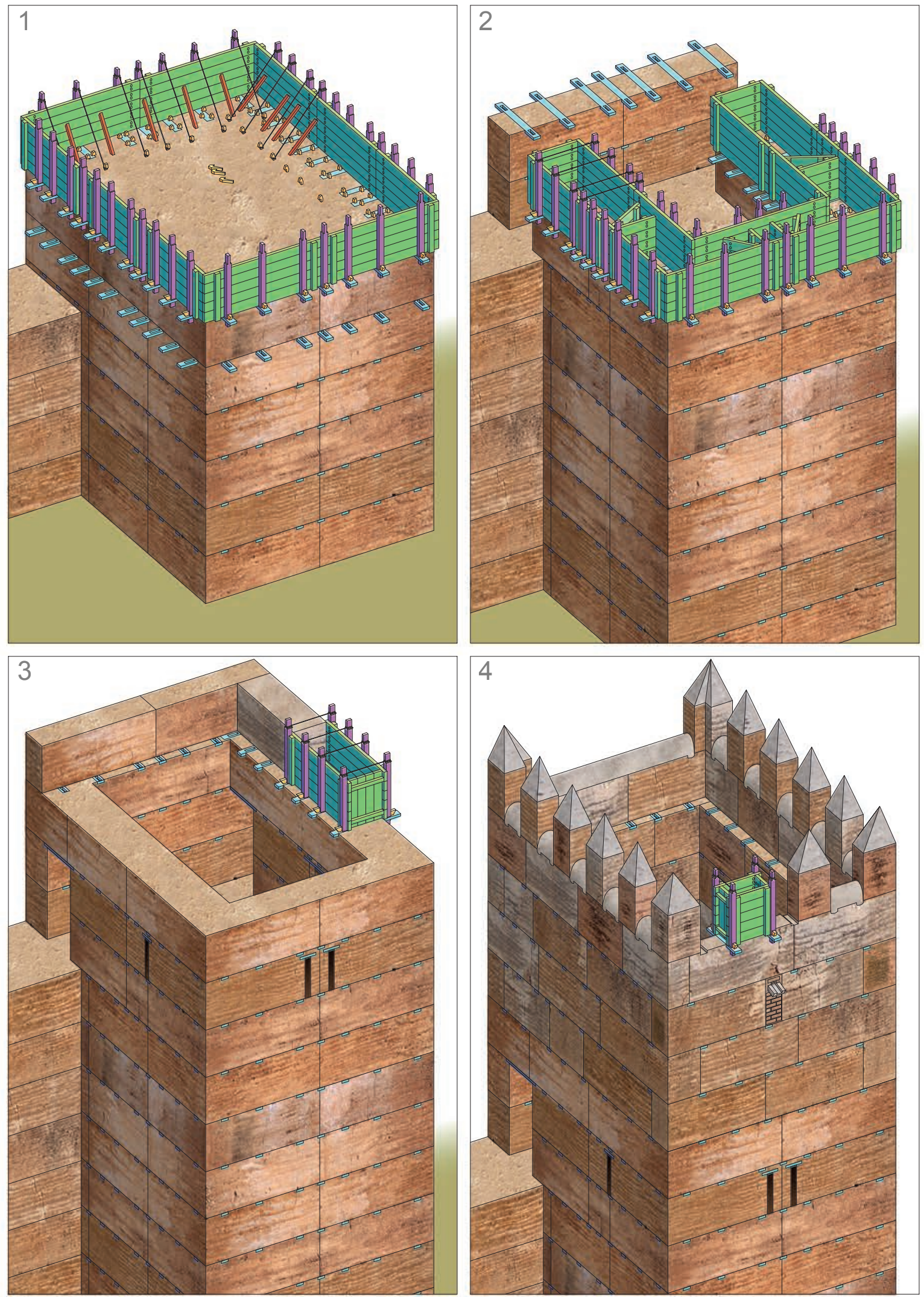

Figura 4. Axonometría del proceso constructivo de las torres de las murallas de la Hoya y San Cristóbal en Almería. Los colores irreales de los elementos de los encofrados responden a un criterio meramente didáctico y de claridad visual. Las agujas y otros elementos perdidos en el encofrado se muestran en tonos azulados, los tapiales en verdosos, los costales en violáceos, los puntales en rojizos, y las cuñas y estacas o clavos en anaranjados. Por otra parte, se ha obviado la representación de los forjados de las cámaras. 
de un encofrado tipo y su disposición en el conjunto, no está de más recordar rápidamente algunos detalles antes de analizar el proceso constructivo de estas torres. De este modo, generalmente sobre los extremos de unas agujas de madera transversales a la base del muro o hilada inferior, se dispondrán unos tableros llamados tapiales que constituirán la horma del encofrado. Cada tapial estará formado por tablones comúnmente horizontales unidos a unos listones verticales mediante clavos metálicos. A su vez, los tapiales quedarán estabilizados en posición vertical por costales anclados en las agujas en la parte inferior y cuerdas en la superior ${ }^{11}$. En el proceso constructivo, los tapiales y costales eran elementos recuperables, de uso continuo; mientras que las agujas solían quedar atrapadas en el hormigón, por lo que sufrían el serrado de sus cabezas. Este esquema clásico para encofrados de módulo reducido sufrirá significativas variaciones en la consecución de encofrados masivos, como se verá más adelante.

Así pues, en una concienzuda observación de la superficie de las tapias, imprescindible para desentrañar el proceso constructivo, se detecta la presencia de rebabas que marcan los límites verticales de cada uno de los tapiales, junto a las huellas de las cabezas de los clavos constituyentes de dichas piezas (Figs. 2 y $3)$. De este modo, se percibe que las dimensiones en planta de las torres vienen determinadas por la longitud y acumulación lineal de los tapiales. En el caso de la torre 10 de la "Muralla de la Hoya", el frente exterior o noroeste viene definido por dos tapiales y los laterales por tres ${ }^{12}$. En la faz exterior de la torre 6 de la "Muralla de San Cristóbal" se añade en medio un tercer tapial muy estrecho que permitirá aumentar la anchura en planta del bastión. En cualquier caso, todos estos tapiales constituirán la horma de un encofrado masivo que afectará a toda la superficie de cada una de las torres (Fig. 4.1); y que se montará, colmatará, desmontará y volverá a armarse por encima, en

\footnotetext{
11 Se recomienda la lectura de López Martínez (1999) en la que se analiza pormenorizadamente la técnica del tapial.

12 Hay que matizar que el enteste de esta torre con la muralla es de lectura paramental problemática. En la cara suroeste del bastión la muralla se adosa a éste, ocultando prácticamente el tercer tapial derecho de cada hilada (Fig. 2). Por el contrario, las hiladas inferiores de la cara noreste se adosan al lienzo adyacente, mientras que las superiores, coincidentes además con las cámaras, parecen recibir las hiladas cimeras del muro, que además se retranquean en relación con las inferiores. Tal adosamiento se aprecia con claridad en las dos últimas hiladas del lienzo (Fig. 1). Por desgracia, la cara intramuros está completamente rehecha en el tramo de la torre, y no puede ofrecer pistas de su relación constructiva con la muralla.
}

idénticas condiciones hasta levantar el macizo de la torre hasta el nivel del adarve. La prueba de ello es el rastro de las rebabas entre tapiales, dispuestas una sobre la otra hasta el nivel del suelo de la primera cámara al menos.

Cada una de las estancias se corresponde en altura con tres hiladas de tapia. En el caso del primero de estos habitáculos, en las faces exteriores se percibe la prolongación de las rebabas que indican que los tapiales se disponían igual que en la parte maciza de la torre. En cuanto a los laterales, las huellas demuestran que tales planchas lignarias se emplazaban del mismo modo que en el macizo, entre las esquinas y las saeteras; pero en el resto del paramento, su ubicación quedaba alterada por la propia saetera y el vano de paso del adarve a la cámara inferior. No obstante, se mantenía la coherencia de montaje de los tapiales en todo el perímetro de la estancia, y en las tres hiladas de tapia que ocupaba. Las saeteras quedaban limitadas por unos tapiales ligeramente más bajos que permitían la disposición de unos tablones cimeros, a modo de dintel. Éstos han desaparecido, seguramente por putrefacción, pero originariamente no eran elementos recuperables, por lo que pasaban a formar parte del bloque constructivo. En conclusión, del mismo modo que en la parte maciza de la torre, la primera cámara se erigía mediante un encofrado continuo, pero en este caso anular (Fig. 4.2).

La cámara superior, como ya se ha referido, carecía de saeteras y tenía unas paredes más finas que la inferior; por lo que se levantó mediante la yuxtaposición de encofrados, siguiendo el proceder más típico en muros delgados (Fig. 4.3). Esto queda probado por la presencia de juntas en vez de rebabas y la consiguiente alteración en el ritmo de los mechinales, determinado por la posición de las agujas. Además, a diferencia de las rebabas que se disponían unas sobre las otras, las juntas aparecen necesariamente contrapeadas para dotar de trabazón y estabilidad a la parte cimera de la torre. En la faz exterior frontal, a la altura de la última hilada de este habitáculo, se emplaza un desagüe de piedra que, junto a los ladrillos circundantes, constituyen los únicos elementos de obra ni de tierra cruda ni lignarios.

Para finalizar, Pretiles y merlatura se conformaban mediante encofrados más delgados, yuxtapuestos y aislados, respectivamente. En el caso de los merlones, cada uno de los cofres se montaba sobre una pareja de agujas, recuperables en este caso, cuyo hueco 
queda disimulado por la media caña correspondiente sobre el pretil ${ }^{13}$ (Fig. 4.4).

Aparte del ilustrativo y revelador ejemplo almeriense, conviene detenerse en Granada, aunque sea brevemente; pues la complejidad arqueológica de las murallas urbanas unida al arduo debate historiográfico abierto sobre su cronología y trazado, excede el objetivo y posibilidades de este trabajo. En resumidas cuentas, de las variadas tipologías constructivas documentadas pertenecientes a distintas líneas defensivas, destacarían entre las más antiguas, dentro de lo taifa, unas torres cuadrangulares de tapia de calicanto con refuerzos esquineros de bloques pétreos en su base y bloques de ladrillos en tramos medios, y tapia terrosa como material exclusivo en la parte superior (García Granados 2014: 488-489; 491, Fig. 2; 493, Fig. 6). En el otro extremo cronológico, en el de las posiblemente últimas realizaciones de los régulos ziríes, tendríamos unas torres semicirculares ejecutadas completamente mediante encofrados, en este caso mediante yuxtaposición de tapiales de planta curva, formalizados por tablones verticales ${ }^{14}$ (Fig. 5).

\section{CONTINUIDAD Y AFIANZAMIENTO: LOS ALMORÁVIDES}

Las atribuciones de fortificaciones andalusíes a época almorávide siempre han resultado historiográficamente problemáticas. Así, los recintos urbanos de Córdoba, Granada y Sevilla, y los castillos de Fuengirola en Málaga y Monteagudo en Murcia, son algunos de los ejemplos que han sido (y son, en ciertos casos) objeto de debate sobre su auténtica filiación. En la actualidad, salvo el caso sevillano, en el que gran parte de su cerca tiende a ser considerada en efecto como obra almorávide, los

\footnotetext{
13 Tales rebajes han llegado a ser confundidos por Pavón (1999: 287-288) con soluciones ornamentales de la arquitectura militar almohade, sin haberlos relacionado con el encofrado. Su análisis y correcta identificación puede consultarse en Márquez y Gurriarán (2003: 94; 2006: 45-46, Lám. 21; 2012: 62, Fig. 2), y Gurriarán y Márquez (2005: 69, Fig. 5).

14 Gómez Moreno (1951: 225) refiere estas torres semicirculares como ziríes. Paz (2015: 41-42) en una de las más recientes revisiones del estado de la cuestión atribuye su erección al último rey zirí, 'Abd Allāh (r. 1073-1090). Incluso, tratando de afinar, sugiere el breve lapso comprendido entre 1075 y 1080 . Por otra parte, García Granados viva vox se muestra de acuerdo con una atribución hacia el final de la taifa, y pone en tela de juicio la adjudicación automática distintas fases a periodos históricos consecutivos (2014: 488) tal y como han hecho algunos autores al sugerir que las murallas paralelas de la cuesta de la Alhacaba se corresponden con una fase taifa y almorávide, como Orihuela (2013: 51). Además, Rabasco (2015: 67-68) insiste en la necesidad perentoria del último monarca zirí en reforzar sus defensas frente a las inminentes amenazas de almorávides y castellanos. No obstante, el proceso de dilucidación del origen de tales torres aun no ha sido satisfactoriamente resuelto, pues Marcos (2015: 195-201) defiende la opción almorávide, en una reciente monografía.
}

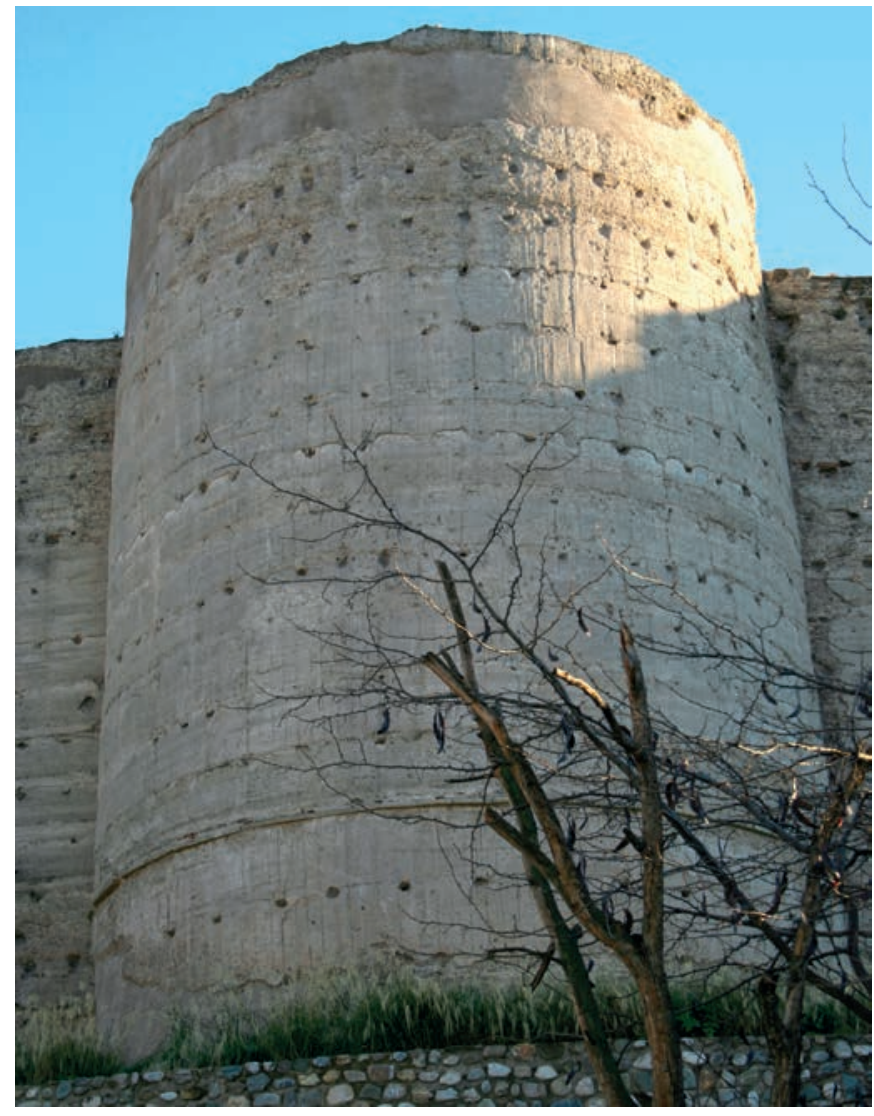

Figura 5. Torre semicircular del tramo superior de las "Murallas de la Alhacaba", en Granada.

otros referidos han causado baja en la lista, o están en tela de juicio ${ }^{15}$. En cualquier caso, las torres subsistentes

\footnotetext{
5 En el lienzo torreado de la Ajerquía cordobesa ha quedado demostrado que los restos visibles se corresponden con la obra bajomedieval del s. XIV, levantada no obstante sobre defensas más antiguas. Léase en Córdoba y Marfil (1995: $147-$ 155), y León (2013: 339-340). La fase almorávide de éstas se detecta en muros de tapia, en los que en ciertos tramos se documentaría el uso de agujas completas, en vez de medias agujas como será usual con los almohades. Las fotografías y planos que documentan las agujas completas se muestran en Bermúdez (2005: 335, Fig. 2; 338, Fig. 6). Esto podría ser indicativo de que el grado de estandarización constructiva todavía no ha llegado a su culmen, como sí sucederá con los Unitarios (vid infra). En el caso de Sevilla, Jiménez y Pérez (2015: 68-69) actualizan el estado de la cuestión, concluyendo que, si bien todavía no se ha resuelto definitivamente el debate, el fiel de la balanza parece inclinarse en favor de un origen almorávide. En cualquier caso, los partidarios de la autoría almohade han ido adelantando su erección hacia los inicios de ese período, entre 1150 y 1157 , por lo que la distancia entre los que defienden la otra opción se ha reducido a un cuarto de siglo. Respecto al Castillo de Fuengirola, López Guzmán (1995: 155) lo menciona como ribat almorávide y refiere ciertos aspectos de su puerta acodada como propios de ese momento. Sin embargo, en la nota 28 reconoce que el único argumento esgrimido para tal datación es el recurso a dos trabajos de Gámir Sandoval y Temboury Álvarez. En VV. AA. (2002: 873-874) se puede constatar que la credibilidad de esos escritos quedaría en entredicho tras la revisión de las crónicas medievales que mencionan Fuengirola; en los que ni es referida como ribat, ni se recoge noticia de época almorávide o posterior que trate sobre ese período. En relación con el Castillo de Monteagudo, Navarro y Jiménez (1995: 64, 72-73; 2012: 296) cierran el debate a favor de una cronología post-almorávide, concretamente bajo el reinado de Ibn Mardanīšs, entre 1147 y 1172.
} 
del recinto hispalense están tan alteradas por reformas y restauraciones que poca información pueden ofrecer para este trabajo, en cuanto a la formalización del proceso constructivo.

Sin embargo, en los últimos años, ha empezado ha estudiarse según un riguroso método arqueológico el yacimiento andalusí de Majāḍat al-Balāt, en la provincia de Cáceres. Las investigaciones en curso han constatado actividad en esta medina desde al menos el s. X hasta su destrucción en 1142, tras el asalto de milicias concejiles de Ávila y Salamanca. Precisamente, tales estudios apuntan que la última fase de su recinto urbano debió erigirse entre 1119 y 1142, bajo administración almorávide (Gilotte, Landou y Callède 2013: 365-366; Landou 2017: 32). Así las cosas, a día de hoy, parece que una de las obras militares andalusíes que puede ser atribuida al período almorávide con mayor certeza es la de la fase postrera de este recinto; cuyo estado de ruina y sin añadidos posteriores resulta esclarecedor para este estudio.

Los vestigios más significativos de esta fase se concentran en la denominada torre 1 , que junto a la cercana 2, pudieran haber servido de flanqueo a un presumible acceso ${ }^{16}$. Este bastión consta de tres fases en las que una pequeña torre cuadrangular de mampostería es forrada por otra similar del mismo material, que a su vez es abrazada y recrecida en época almorávide por una obra de mampostería y tapia (Fig. 6). De esta manera, encima del zócalo de mampuestos se erigen cinco hiladas de obra encofrada con refuerzos esquineros pétreos, sobre los que se levantan otras cinco más. Se desconoce si la parte cimera conservada coincide con el terrado o dispuso de cámara. Los refuerzos angulares de mampostería, parcialmente perdidos por el desmoronamiento de los laterales de la torre, estaban compuestos por bloques paralelelipédicos dispuestos en cremallera y, curiosamente no guardan simetría en la fachada exterior. Pero lo más relevante es la disposición de una serie de postes y vigas en el interior de la argamasa, actualmente desaparecidos, pero cuya huella resulta evidente por el mencionado derrumbe de las esquinas. Así, se observan los huecos de tres maderos horizontales, dispuestos en paralelo a la faz exterior de la torre: el inferior coincidiendo con la base

\footnotetext{
16 Ante la ausencia de denominaciones específicas para estas torres, se han asumido las atribuidas en los más recientes y concienzudos trabajos sobre este yacimiento. Véase en Gilotte, Landou y Callède (2013: 359-361), y Landou (2017: 27, 31).
}

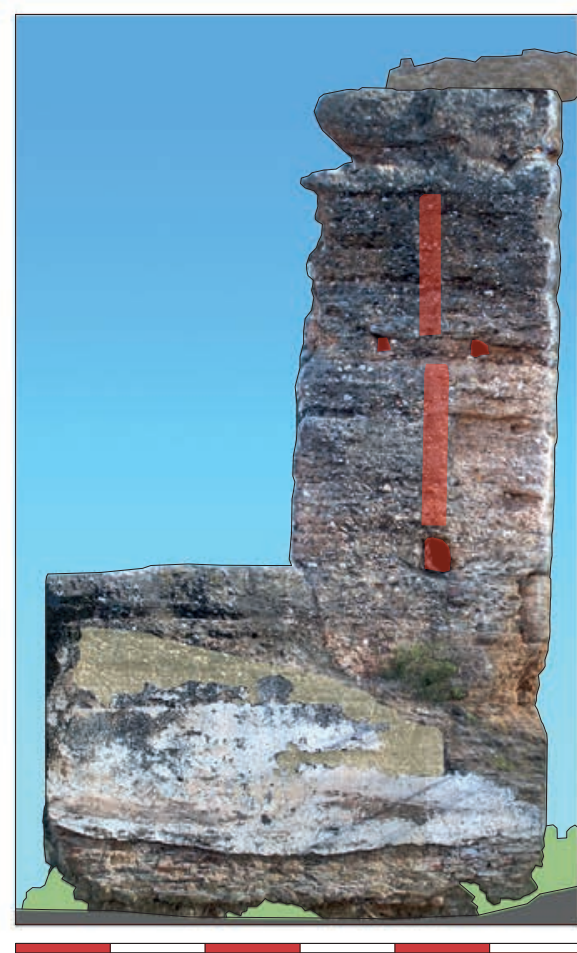

0

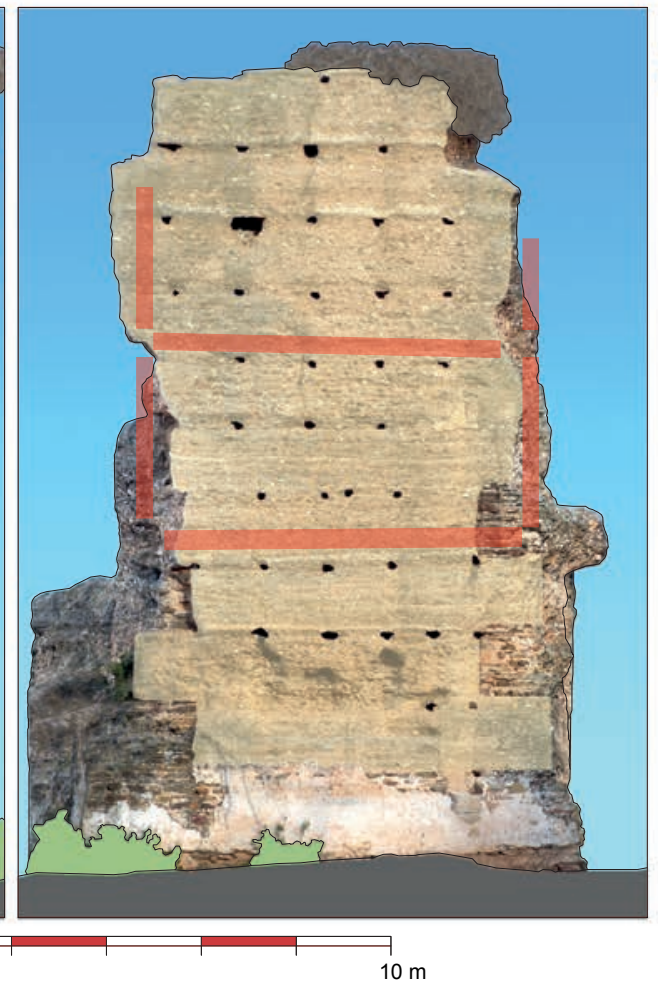

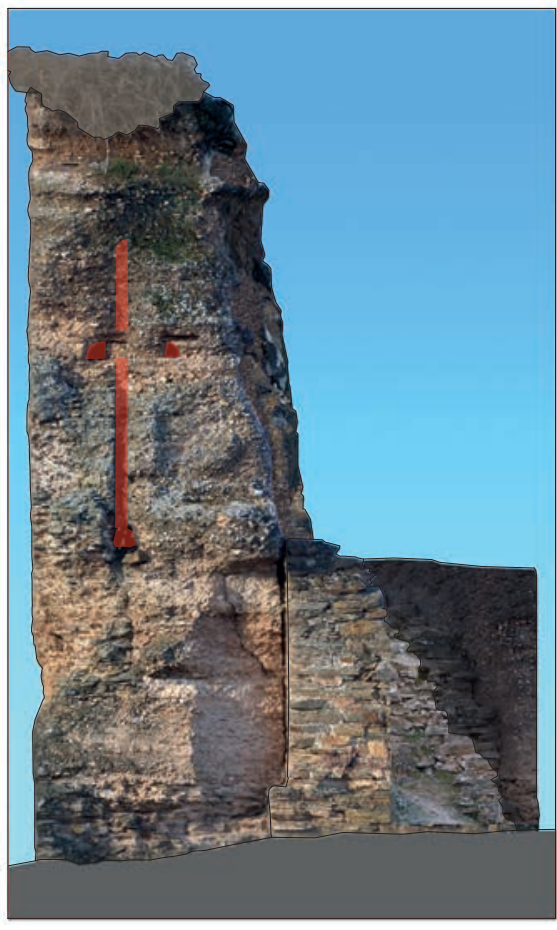

Figura 6. Ortoalzados, de nube de puntos, realizados con la colaboración de Pedro Gurriarán Daza; de las caras este, sur y oeste de la torre 1 del recinto urbano de al-Balāț. Las huellas de los elementos lignarios perdidos en el encofrado se han marcado en rojo suave, y La superficie original de las tapias en ocre. 
de la cuarta hilada de tapia y los dos superiores, uno tras otro, en la base de la séptima. Los postes verticales coinciden con los extremos aparentes de la primera viga horizontal y abarcarían desde la cuarta a la novena hilada al menos. No queda claro si tales postes se disponían por dos parejas sucesivas o las huellas responden a un par de piezas tan largas como las vigas. En cualquier caso, ésta es la más antigua constatación de elementos lignarios perdidos en el interior de una obra encofrada que pudieron tener una doble función. Por un lado, sería factible que las vigas hubieran servido para armar interiormente ciertas hiladas, ya que todas parecen resueltas mediante encofrado continuo. Por otro, los postes verticales también pudieron cumplir cierta labor estructural, pero también servir de estacas en las que atirantar los tapiales para evitar su vuelco al exterior. Sea como fuere, lo que queda claro es que la disposición de estos elementos lignarios no es ni mucho menos aleatoria o descuidada. Más bien parece responder a una estructura de "parrilla" destinada a dotar de solidez a una obra no masiva, como las vistas anteriormente, sino que servía de forro a una obra previa y de la que interesaba que tuviera cierta autonomía. A pesar de la desaparición de la madera, este objetivo habría quedado cumplido, puesto que el forro ha sobrevivido en altura a la torre que abrazaba, únicamente conservada en su parte inferior. Paradójicamente, la presencia de los postes tan cercanos a los ángulos del forro, con sus dilataciones y contracciones ha propiciado la ruina de las esquinas del bastión; reventado precisamente por donde estaban éstos situados.
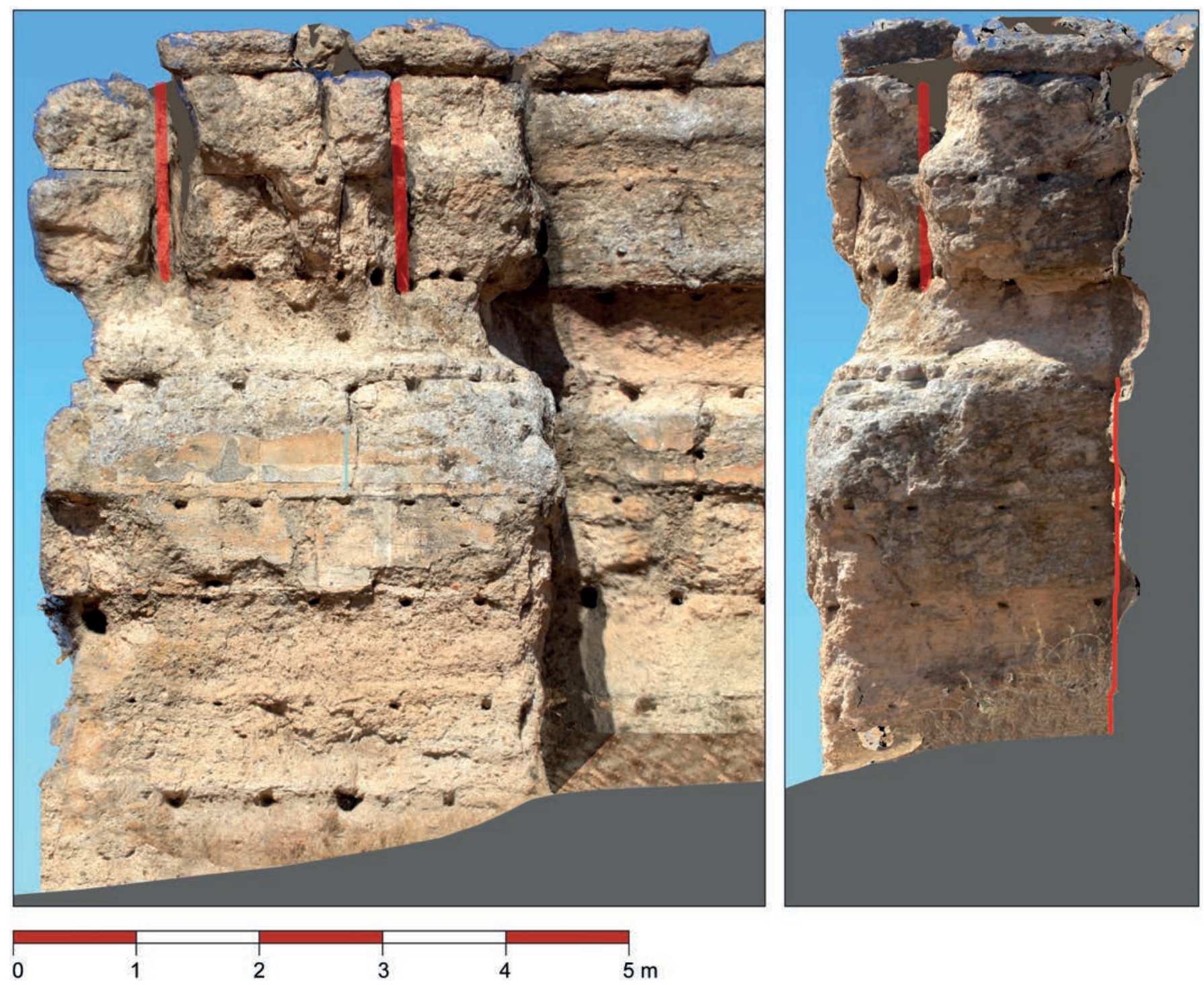

Figura 7. Ortoalzados, de nube de puntos, realizados con la colaboración de Pedro Gurriarán Daza; de las caras sureste y noreste de la torre del extremo meridional de la fortaleza de El Vacar. Las huellas de los postes de arriostrado de los tapiales se indican en rojo suave, las rebabas en azul y las juntas en rojo. 


\section{LA GRAN ECLOSIÓN CONSTRUCTIVA ALMOHADE}

Durante el período de implantación del poder almohade en al-Ándalus se dieron las circunstancias para que se produjera una eclosión en la edificación, sin precedentes en todo el medievo hispano. El aumento de la presión militar de los reinos cristianos acarreó un espectacular incremento de obras de fortificación de todo tipo y función; que, por otra parte, supuso una importante herramienta política de la propia dinastía promotora. Precisamente, bajo los Unitarios, la arquitectura monumental adquiere un matiz especial como vehículo de transmisión del mensaje político, mediante la estandarización de formas arquitectónicas y soluciones epidérmicas, especialmente evidentes en edificaciones militares ${ }^{17}$. Tales necesidades edilicias tuvieron también un importante efecto en la depuración, extensión y uniformación de los propios modos constructivos.

En el apartado anterior se habían referido los primeros ejemplos documentados acerca de la disposición de grandes elementos lignarios no recuperables en el hormigón. A partir del momento que nos ocupa, será muy habitual encontrar huellas de postes de atirantado de los tapiales en el interior de las torres, tal y como se constata en Alcácer do Sal, Juromenha, El Vacar, Reina, Écija ${ }^{18}$ y Gibraleón ${ }^{19}$, por citar los

\footnotetext{
17 Se tratan estas cuestiones en Azuar (2005), Márquez y Gurriarán (2008) y Villalba (2015: 64).

18 La filiación almohade de estos recintos se puede consultar, en el caso de Alcácer do Sal en Pavón (1993: 16-17), VV. AA. (2001: 174175), Azuar (2005: 127, 130), Cottart (2012: 198) y Villalba (2016: 86). En el caso de Juromenha, Branco y Picard (1992: 84-85) empleando paralelos incorrectamente identificados y criterios cronotipológicos un tanto imprudentemente, proponen que las tapias puedan responder a obras aftasíes del s. XI. No obstante, hay otros autores que se decantan por una datación almohade. Léase en VV. AA. (2001: 98) y Villalba (2016: 86) En nuestra opinión, ciertos vestigios de acabados epidérmicos de una de las torres, erigida en la fase de reforma masiva de la fortaleza mediante obra encofrada, también se vincularían a revestimientos documentados a partir del s. XII, por lo que la cronología propuesta por los últimos autores nos resulta más verosímil. El caso de Reina se puede ver en Navareño (1998: 188), Pavón (1999: 125) y Márquez y Gurriarán (2011: 198); y Écija en Hernández, Sancho y Collantes de Terán (1951: 211-212) y Valor (2004: 152).

19 Pavón (1996: 42) describe los vestigios defensivos de Gibraleón pero sin ofrecer mayores precisiones cronológicas, salvo de una de las torres, para la que propone el siglo X. El mismo autor (1999: 201) refiere la fortaleza como árabe. Para Carriazo y Cuenca (2004: 190) la actual fortaleza bajomedieval fue erigida entre los siglos XIII y XIV sobre los cimientos de una islámica anterior. Pérez (2014: 211) recoge testimonios documentales de que a partir de 1267 se destinaron importantes recursos económicos para la reconstrucción y reparación de la muralla y sus torres. No obstante, aunque la torre de este recinto mostrada en la figura 12 pudiera haberse erigido tras la conquista cristiana, tecnológicamente está anclada en los modos constructivos de obra encofrada habitualmente documentados en época almohade.
}

casos en los que su estado ruinoso ha permitido su observación ${ }^{20}$.

En varias torres de El Vacar se aprecian las huellas de postes, que atravesaban al menos dos hiladas de tapia, uniformemente dispuestos formando un cuadrilátero a poco más de un metro de los ángulos de la construcción (Figs. 7 y 9). Del mismo modo que en al-Balāt (vid supra), en este caso estos maderos han sido la causa de la ruina de las esquinas.

Por otra parte, el empleo de fábricas mixtas, documentado en las más antiguas obras taifas granadinas y al-Balāt (vid supra), tenderá a generalizarse. En Reina, Carmona, Cáceres, Badajoz, Juromenha, Niebla, Saltés, Gibraleón, Jerez de la Frontera ${ }^{21}$ y Palma del Río, por citar algunos ejemplos, se reforzarán las esquinas de algunas torres mediante bloques de mampostería, ladrillos o sillares. En el caso de Reina, la disposición de tales refuerzos en una de las torres, más los datos proporcionados por la ruina parcial de la obra, permitiría una propuesta de recreación de su erección (Figs. 10 y 11). Esto nos permite comprobar de nuevo el empleo de encofrados masivos en cada hilada, cuestión que queda probada por la presencia de postes de atirantado cuya huella era visible en la parte superior de la construcción. No obstante, por analogía con la posición de estos elementos lignarios documentada en al-Balāț, El Vacar (vid supra), y Gibraleón (Fig. 12), se propone la disposición de tal maderamen según un cuadrilátero, de modo que dos postes estarían sobre la unión de la torre con el lienzo y los otros dos muy cerca de los bloques angulares de sillares y ladrillo. Además, las huellas de las rebabas de los tapiales y posición de agujas pareadas junto a éstas abundan en la colocación de tales planchas de madera formando un único encofrado por nivel o hilada. Eso sí, en este caso las rebabas se van contrapeando innecesariamente, desde un punto de vista constructivo. Esto mismo se aprecia en la cacereña Torre del Horno, aunque en esta ocasión las rebabas quedan disimuladas por las cintas verticales del acabado epidérmico original

\footnotetext{
20 La presencia de postes con idéntica función y emplazamiento se recoge también en obras militares cristianas tardías, tecnológicamente similares. Véase en Valor (2009: 426, Fig. 4). No obstante, la autora identifica tales restos con una plataforma de tapia que sirvió de base a una torre de madera (2009: 430-431), opinión que no suscribe el firmante de este trabajo.

${ }_{21}$ La paternidad almohade de estas fortificaciones se puede consultar, en el caso de Carmona en Valor (2007: 134); Cáceres en Torres (1948: 466) y Márquez y Gurriarán (2003: 97-102); Badajoz en Torres (1941: 178), Márquez y Gurriarán (2011: 193-196; 2012: 71-73) y Sánchez (2013: 90-91); Niebla en Pérez et al. (2000: 117) y Valor (2007: 140-141); Saltés en Carriazo y Cuenca (2004: 82), aunque se le adjudica un impreciso s. XII; y Jerez de la Frontera en González y Aguilar (2011: 11).
} 

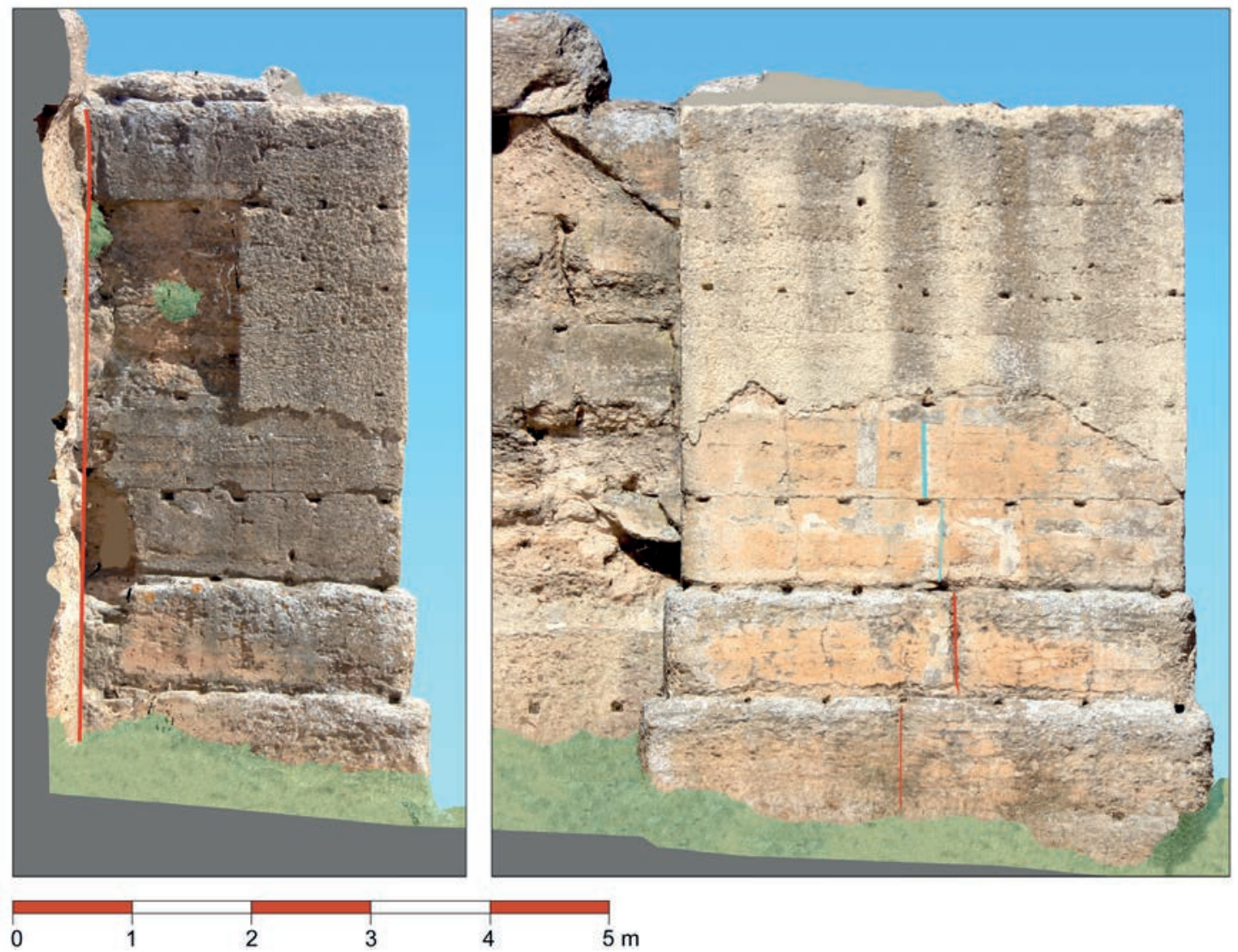

Figura 8. Ortoalzados, de nube de puntos, realizados con la colaboración de Pedro Gurriarán Daza; de las caras suroeste y sureste de la torre del extremo oriental de la fortaleza de El Vacar. Las rebabas se indican en azul y las juntas en rojo.

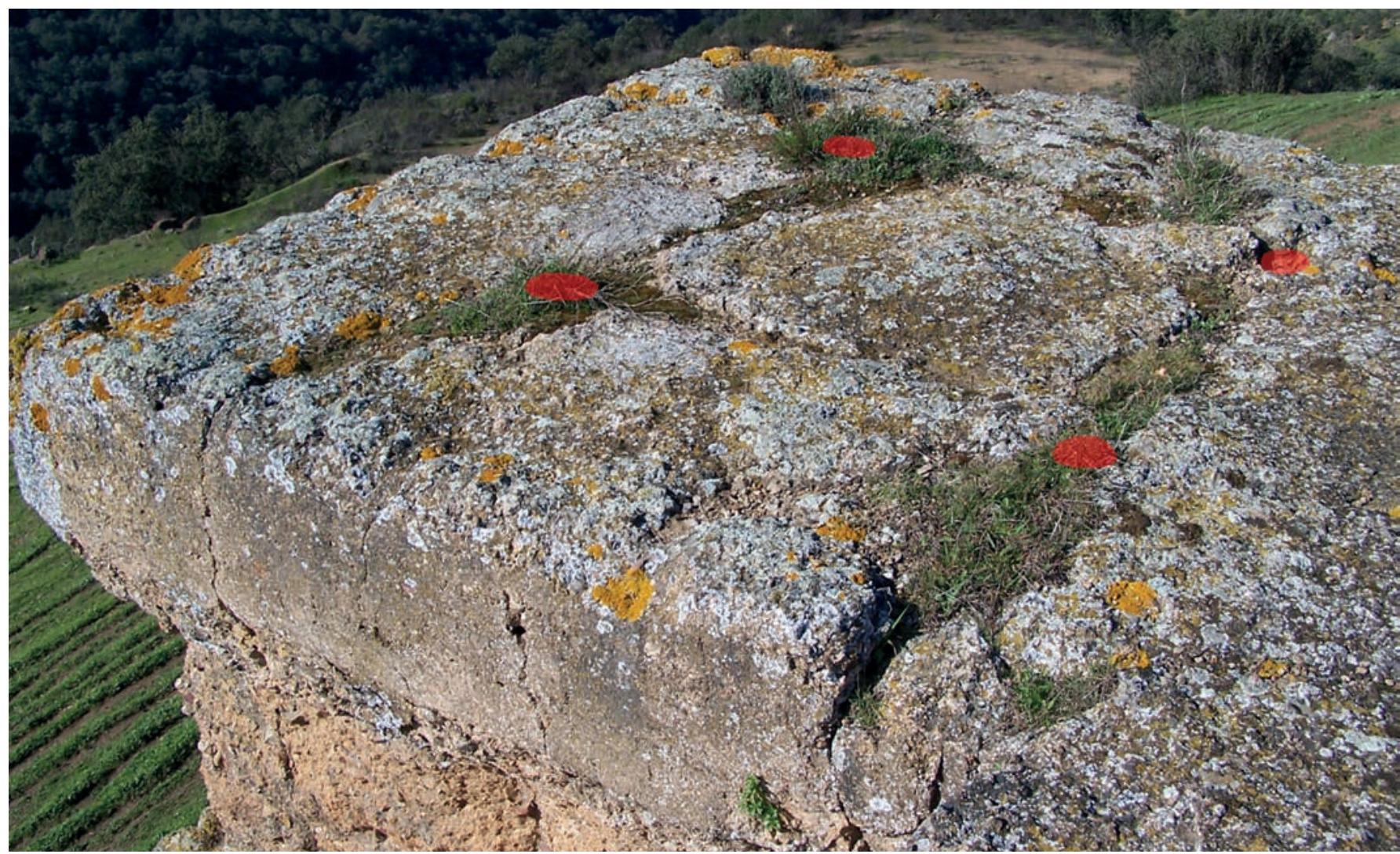

Figura 9. Parte cimera actual de la torre intermedia del lienzo suroeste de la fortaleza de El Vacar. Las huellas de los postes de arriostrado se marcan en rojo. 


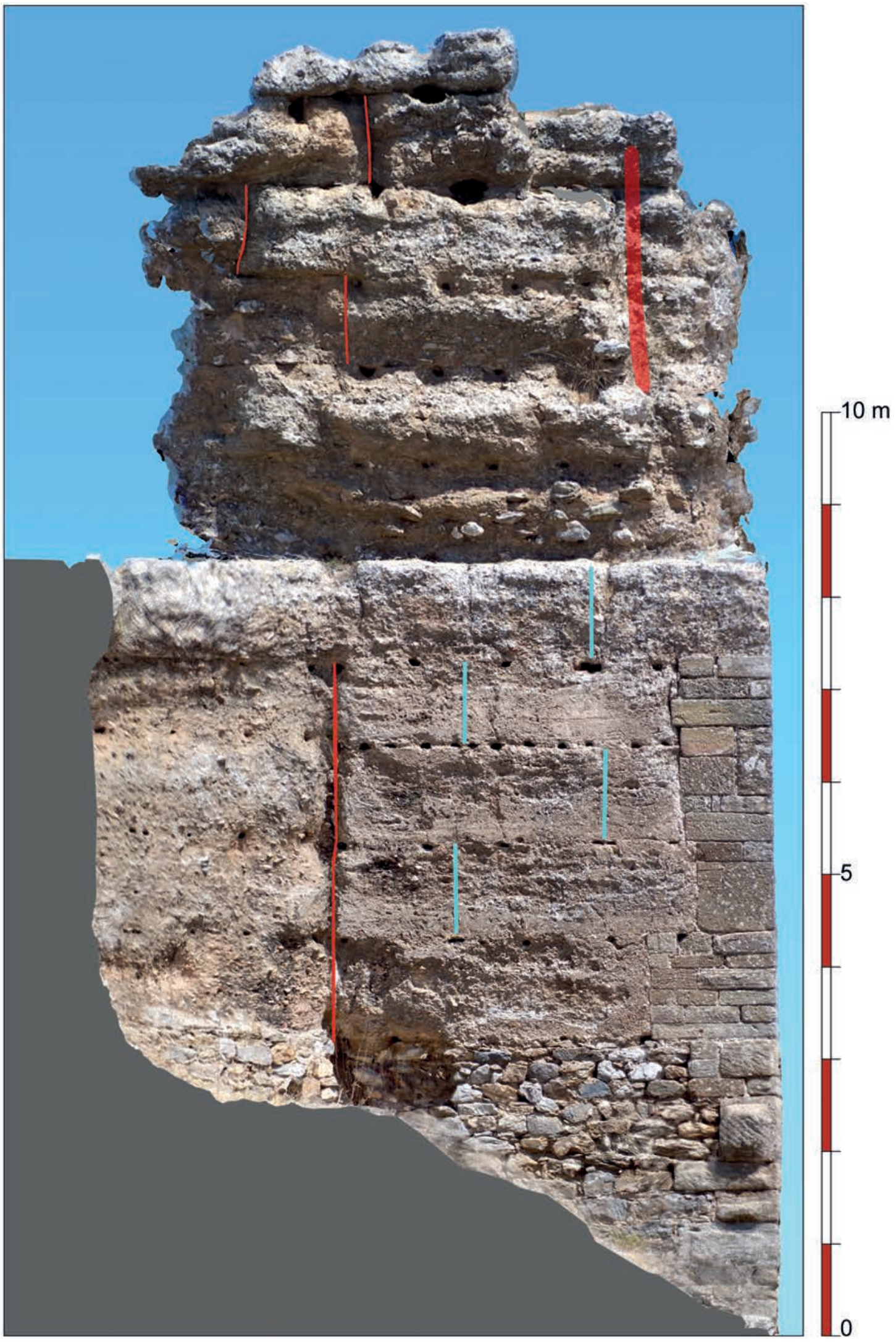

Figura 10. Ortoalzado, de nube de puntos, realizado con la colaboración de Pedro Gurriarán Daza; de la faz suroeste de la torre de extremo oriental del recinto de Reina. Las rebabas se indican en azul, las juntas en rojo y los postes de arriostrado en rojo suave. Las fotografías empleadas en la elaboración del ortoalzado fueron tomadas el 8 de julio de 2004, con anterioridad a la restauración que ha modificado profundamente el estado de las seis hiladas superiores. 


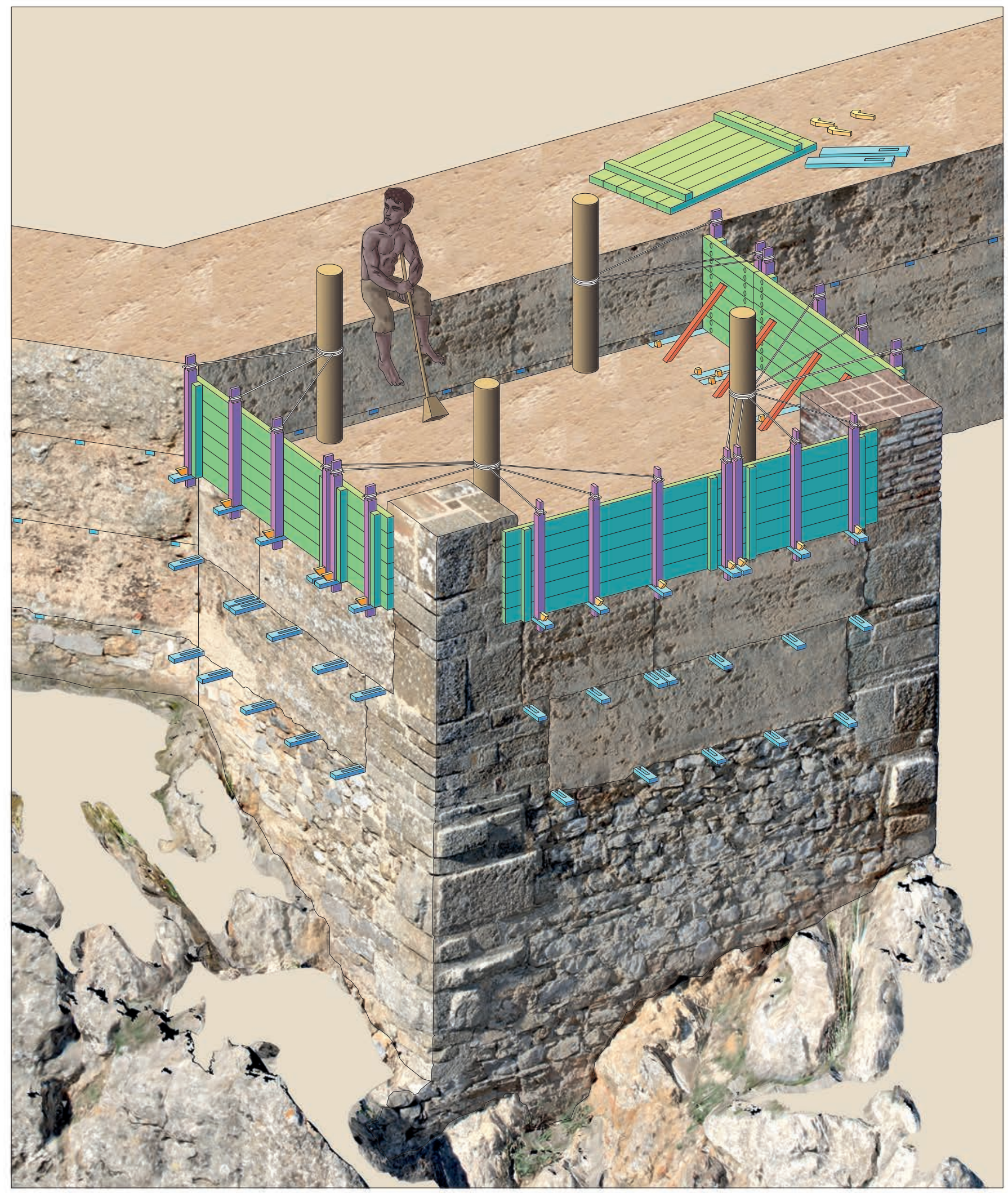

Figura 11. Axonometría, sobre imagen de nube de puntos, realizada con la colaboración de Pedro Gurriarán Daza, del proceso constructivo de la torre del extremo oriental del recinto de Reina. El criterio cromático de los elementos del encofrado es el mismo que el de la figura 4. 


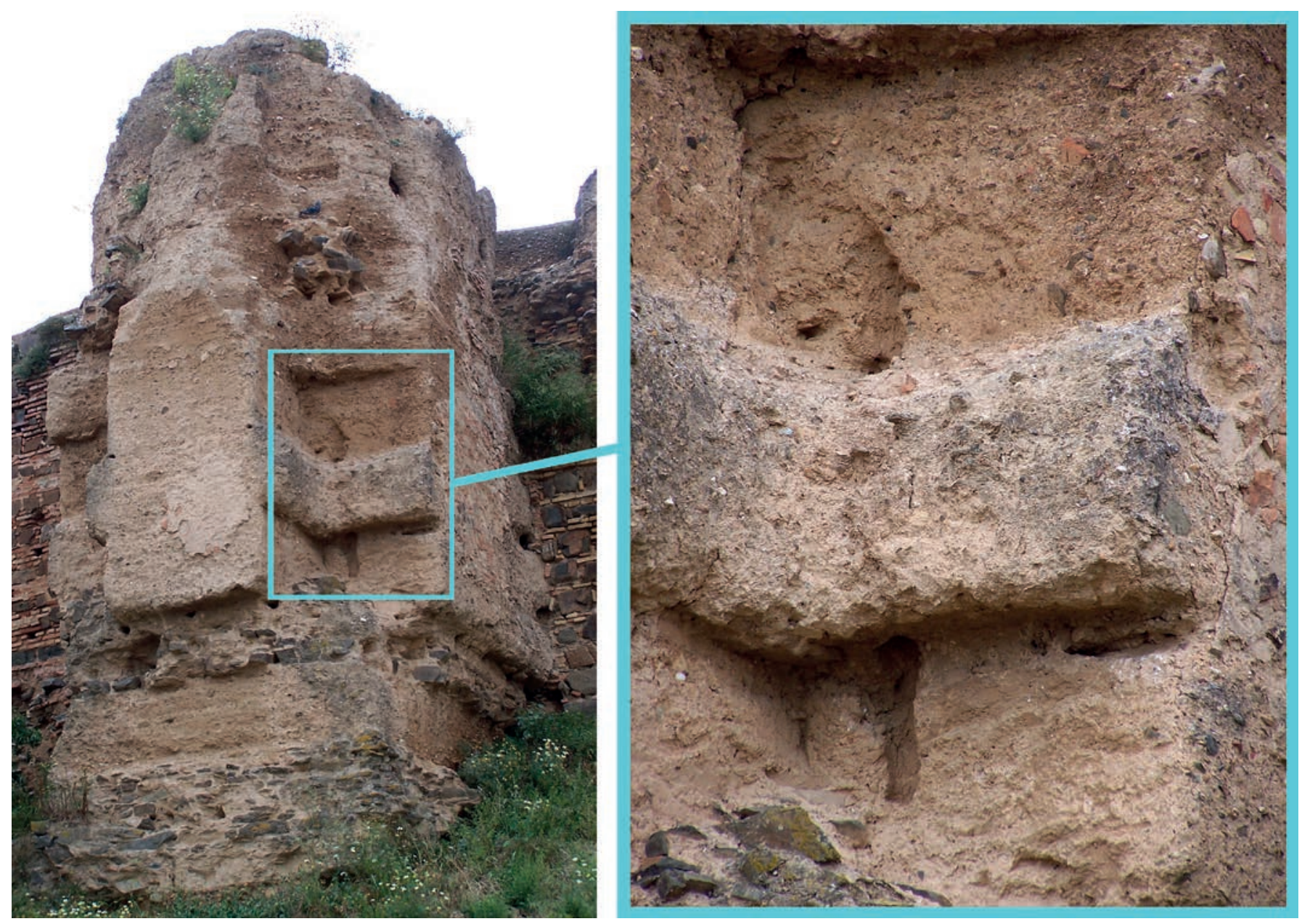

Figura 12. Torre norte del recinto de Gibraleón, con detalle de la huella de poste de arriostrado que atraviesa tres hiladas de tapia, por detrás del desaparecido encadenado esquinero, presumiblemente de mampostería.

(Fig. 13). Aparentemente, el motivo subyacente del innecesario contrapeado no sería otro que el de una fina ejecución de obra. Sin embargo, abundan los ejemplos de torres almohades, o mardanisíes coetáneas, en los que, al igual que lo documentado en Almería (vid supra), los tapiales se irán disponiendo del mismo modo, hilada tras hilada, como demuestran las líneas corridas de rebabas con sus respectivas huellas de cabezas de clavos. Así se aprecia en el Castillo de Monteagudo, Alcácer do Sal, Palma del Río, Jorquera o Villena ${ }^{22}$, por citar algunos ejemplos (Figs. 14 y 28).

Otra cuestión que se plantea es la trabazón entre una torre y el lienzo adyacente. En la torre oriental de Reina se aprecia cómo sus cuatro primeras hiladas de

22 Véase la adscripción almohade de Jorquera en Cebrián (2008: 42) y Pretel (2011: 23); y de Villena en Azuar (2005: 133) y Almagro, Soler y Soler $(2014: 11,18)$, en cuyo caso la cronología ha sido refrendada arqueológicamente. tapia de se adosan al lienzo, por la claridad de las juntas constructivas y por la no correspondencia en altura entre las hiladas de ambos elementos (Fig. 10). Sin embargo, en el quinto hilo, que es el primero sin refuerzos esquineros, se produce la trabazón y coincidencia en altura entre torre y lienzo. De ahí para arriba se irán alternando hiladas trabadas y adosadas.

En varias torres de El Vacar se observa un planteamiento similar, en el que éstas y los lienzos se erigen como bloques adosados, hasta que se traban en las hiladas superiores ${ }^{23}$ (Figs. 7 y 8). En el recinto urbano de Sevilla se ha detectado un proceder parecido, pero en este caso en las hiladas inferiores la muralla se adosa a las torres $\mathrm{y}$, por el contrario, en las superiores las torres

\footnotetext{
23 Hunt (2001: 818) describe semejante disposición en la fase almohade del Castillo de San Jorge. Gurriarán y Sáez (2002: 606-607), y Jiménez y Pérez (2012: 294) niegan atribuir, de manera automática, un sentido de correlación cronológica a la existencia de hiladas adosadas y trabadas.
} 


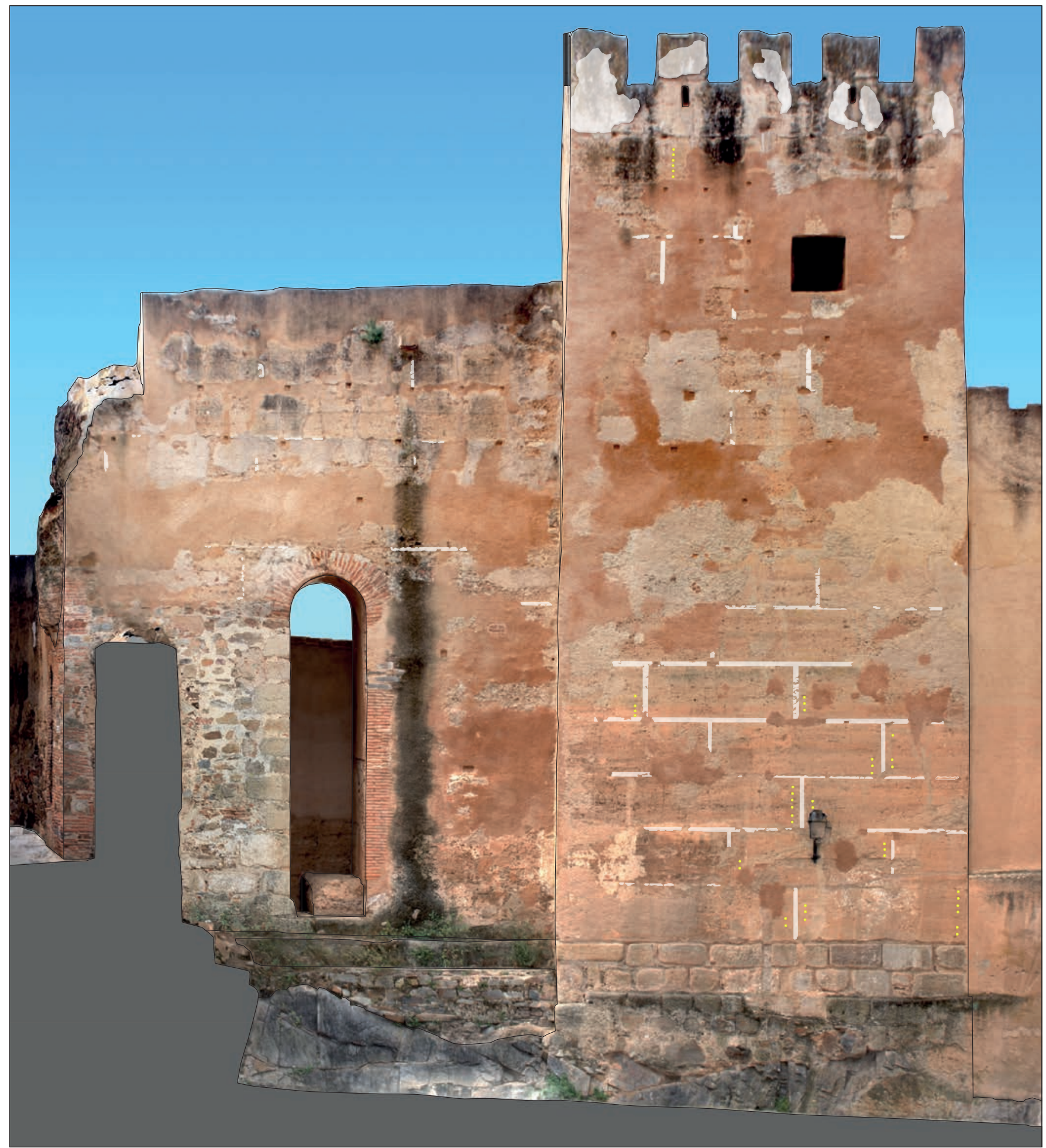

0

Figura 13. Ortoalzado, de nube de puntos, realizado con la colaboración de Pedro Gurriarán Daza; de la faz noreste de la torre albarrana del Horno. Se han destacado en blanco los vestigios del encintado y jabelga del pretil y merlatura del terrado, y en amarillo las huellas de las cabezas de los clavos de los tapiales. 

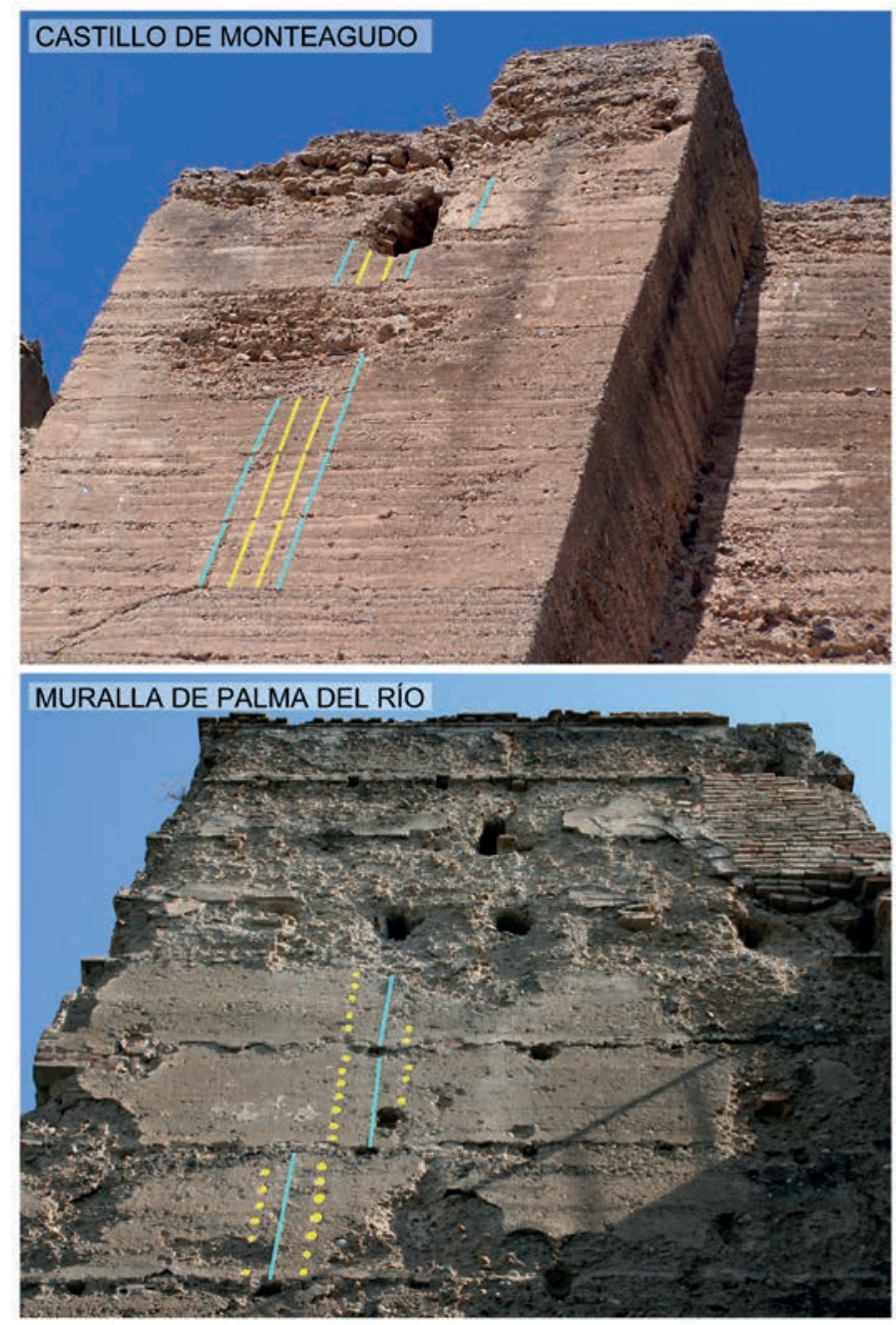

Figura 14. Paramentos de torres con indicación de rebabas de los tapiales en azul y tablones verticales y huellas de cabezas de clavos en ama rillo. Nótese la similitud en la disposición de los tapiales entre la fotografía del Castillo de Monteagudo y la torre de la figura 3.

se adosan al muro ${ }^{24}$. En resumidas cuentas, todos estos juegos de trabazones y adosamientos documentados al menos desde época taifa (vid supra), podrían estar orientados a la creación de una especie de machihembrado para dotar de solidez y estabilidad a la obra. Esta cuestión se hace evidente incluso en algunas albarranas, como la Torremochada de Cáceres, en el que el espigón penetra con claridad en el macizo de la torre poligonal (Márquez y Gurriarán 2003: 77).

En cuanto a la probable función de armado de las vigas horizontales perdidas en el interior del encofrado, según se vio en al-Balāt (vid supra); posiblemente en esta época se podría certificar semejante cometido. De confirmarse la cronología sugerida, así lo demostrarían

\footnotetext{
24 Así lo confirma arqueológicamente Pozo (2008: 140-141, 151-152) en el tramo de la Macarena.
}

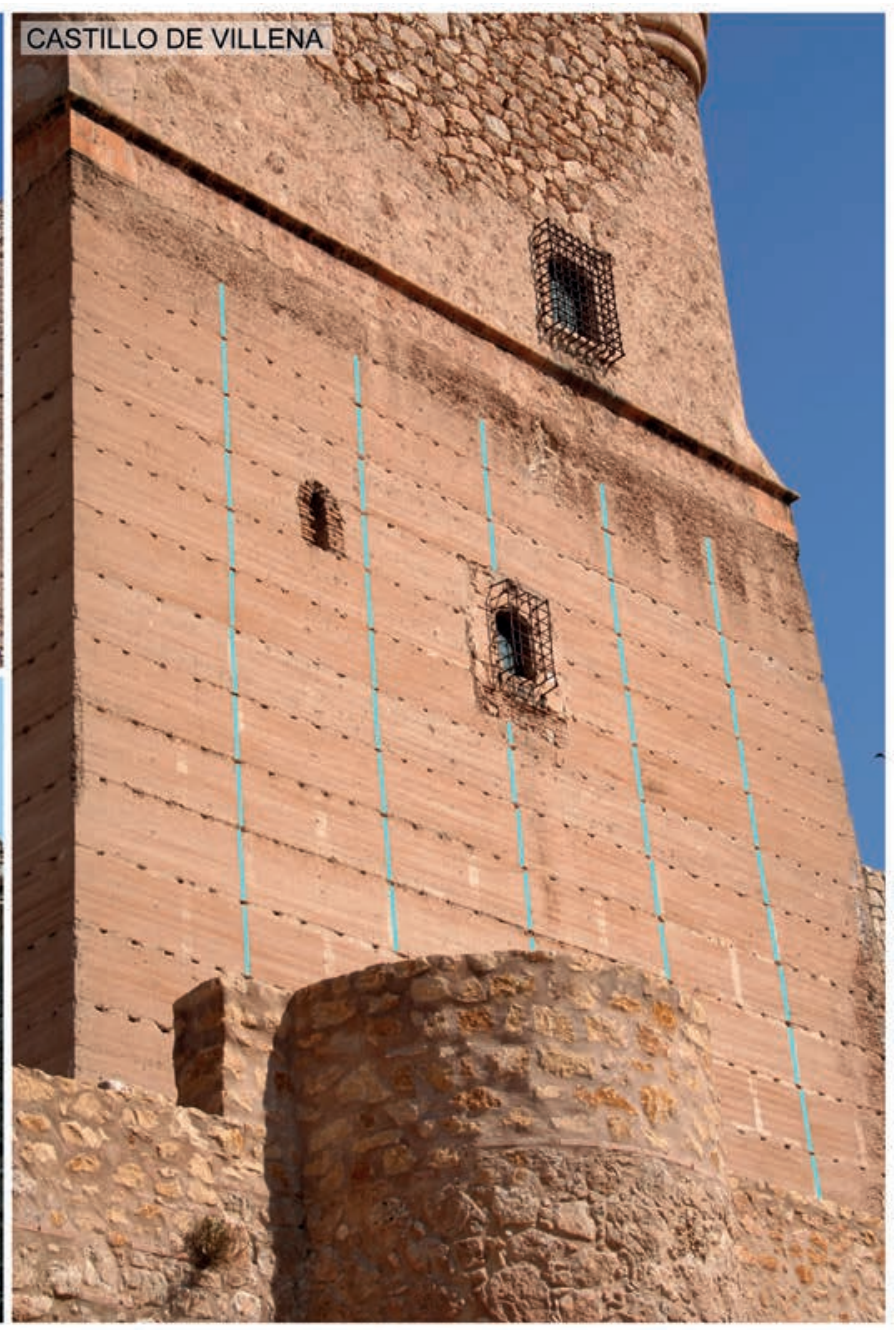

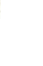



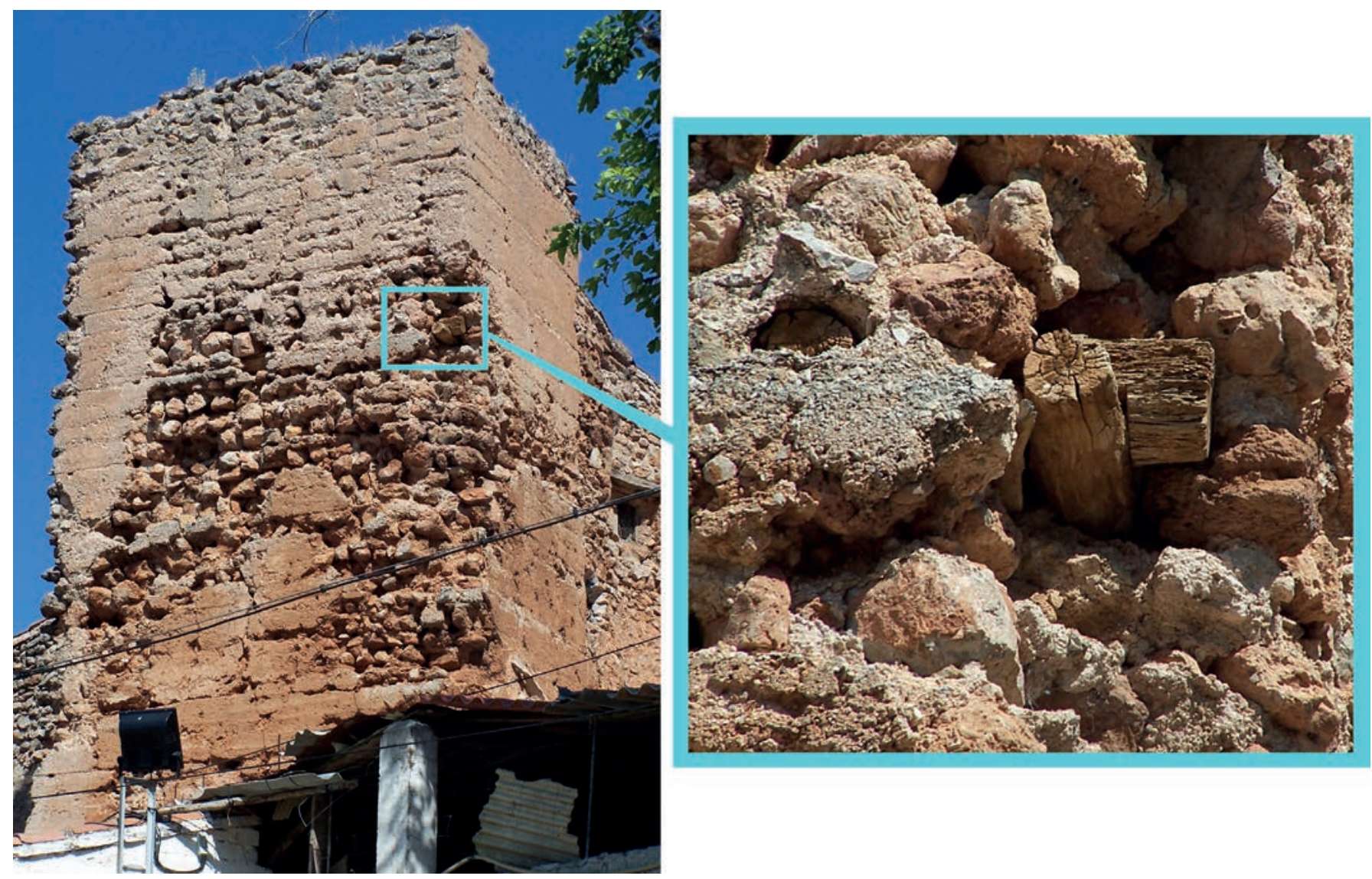

Figura 15. Torre del recinto urbano de Hornos de Segura con detalle de las cabezas de las vigas ensambladas en sus extremos.

gracias a unos rebajes previamente tallados (Fig. 16). Tal trabazón estaría sin duda destinada a aumentar la cohesión entre las distintas caras de la torre.

En torres macizas también se ha documentado la presencia de travesaños que arman ciertas hiladas, como en la Torre del Aire en la cerca cacereña, en la que tales elementos lignarios se disponían aproximadamente de forma radial (Márquez y Gurriarán 2017: 213, Fig. 5; 214).

Merece la pena detenerse en un elemento singular, habitualmente presente en pretiles y cámaras, y que experimentará una particular evolución constructiva en su formalización como obra encofrada. Nos estamos refiriendo a la saetera, cuyos ejemplos más antiguos documentados son los descritos en las torres taifas de Almería (vid supra). En las fortalezas almohades del sureste peninsular es habitual encontrar estos elementos, formal y tecnológicamente resueltos de la misma manera que en Almería, sin que se haya producido evolución alguna. En cualquier caso, este procedimiento resultaba ya en época almohade un tanto arcaico y muy mejorable en lo que a recuperación de materiales lignarios se refiere, pues recordemos que el dintel, generalmente compuesto por tablillas, quedaba embebido en la argamasa. Ocasionalmente, tales tablillas estaban tomadas de material de desecho, anteriormente destinado a otras partes del encofrado; tal y como se aprecia en la fortaleza almohade de Baños de la Encina, en la que son reutilizadas unas agujas, perfectamente identificables por los orificios cuadrados de sus extremos (Fig. 17). El panorama es muy diferente en el bajo Guadalquivir y occidente andalusí, en el que las saeteras se resolverán mediante hormas, muy posiblemente constituidas por una sola pieza con forma de artesa oblicua. En este caso, estos moldes se depositaban en el interior del encofrado y tras su colmatación y desmonte de tapiales, eran perfectamente recuperables y reutilizables. Por otra parte, su formalización era más sofisticada, pues frente a las saeteras tradicionales de base y techo horizontales, éstas quedaban delimitadas por planos inclinados arriba y abajo (Fig. 18). Así se aprecia claramente en Cáceres, Elvas $^{26}$, Sevilla y Carmona. El último eslabón evolutivo

\footnotetext{
Se refieren las obras almohades de Elvas en VV. AA. (2001: 96-97), Branco (2002: 361, 364), Márquez y Gurriarán (2008: 133-134; 2011: 196197) y Villalba (2016: 86).
} 


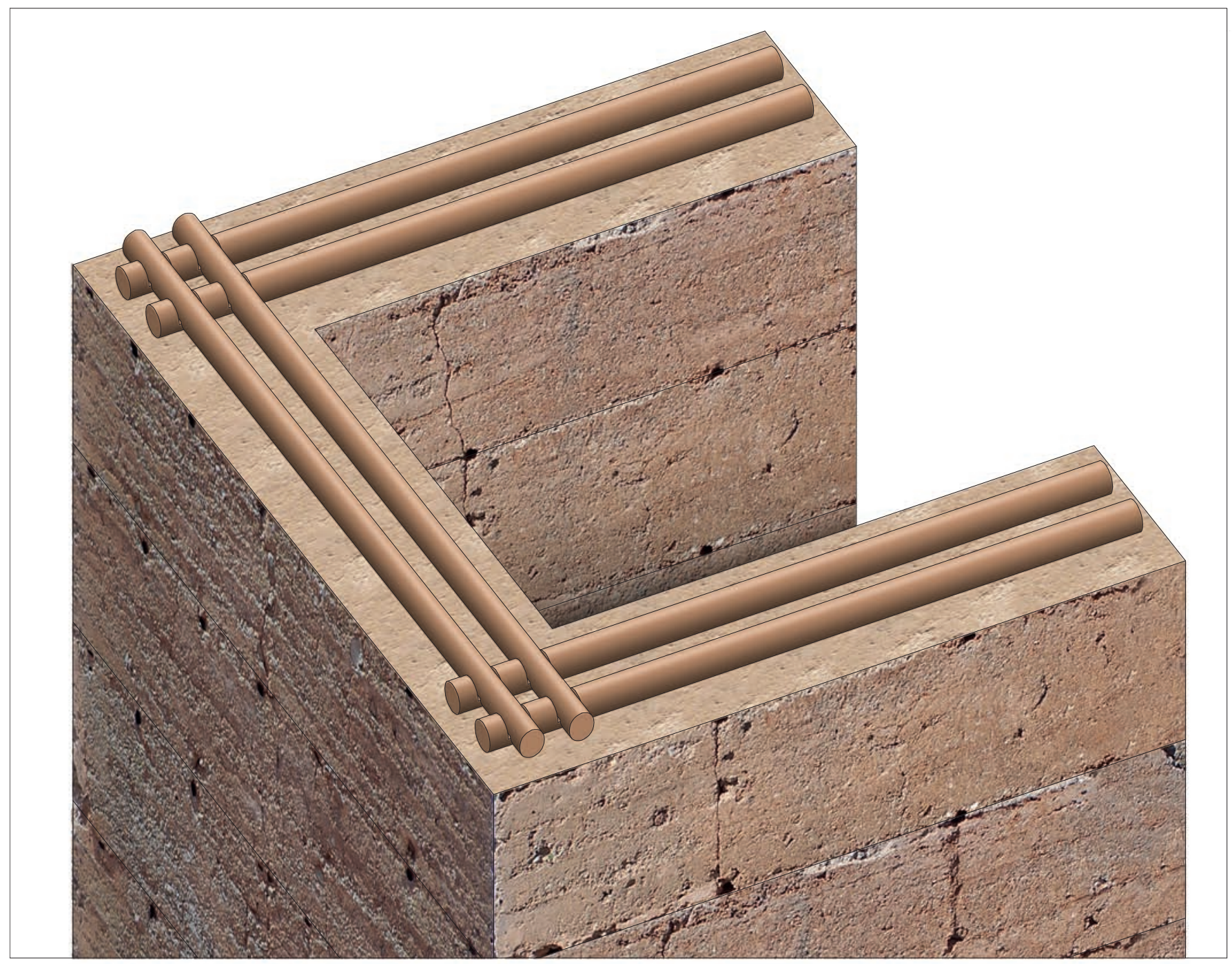

Figura 16. Axonometría de la recreación de la disposición de las vigas que arman una de las hiladas de la torre del recinto de Hornos de Segura.

quedaría definido por saeteras de obra, habitualmente latericia, ejecutadas previamente al encofrado del muro o pretil en que se dispusieran. Con la gran ventaja de que resultan prácticamente inmunes al desgaste antrópico, climático o mecánico (Fig. 19). Hasta la fecha no ha sido posible documentar más casos que en Badajoz ${ }^{27}$, Palma del Río y Sevilla. De cualquier manera, esta tipología está vinculada fundamentalmente a aquellas obras almohades en las que se hace patente la inclusión de ladrillo como material auxiliar relevante.

\footnotetext{
27 En Márquez y Gurriarán (2012: 62, Fig. 2) se muestra, en el contexto del proceso de erección de una torre completa, la construcción de las saeteras de la cámara, a modo de bloques de ladrillo entre encofrados angulares.
}

\section{LA EVOLUCIÓN DE LOS TRATAMIENTOS EPIDÉRMICOS}

Los datos de los que actualmente disponemos apuntan a un doble panorama en época taifa. Por un lado, en el recinto de Almería, los tratamientos epidérmicos tras el desencofrado parecen haber sido nulos, pues no se aprecia la más mínima huella en todas las superficies que han llegado intactas a nuestros días. Precisamente, el hecho de que se hayan conservado tan bien da la impresión de que los constructores fiaron la resistencia de las faces exteriores a la propia dureza de las tapias eficazmente calicastradas. Por otra parte, en uno de los más antiguo recintos de ese período en Granada, sí se documenta un acabado superficial consistente en una 


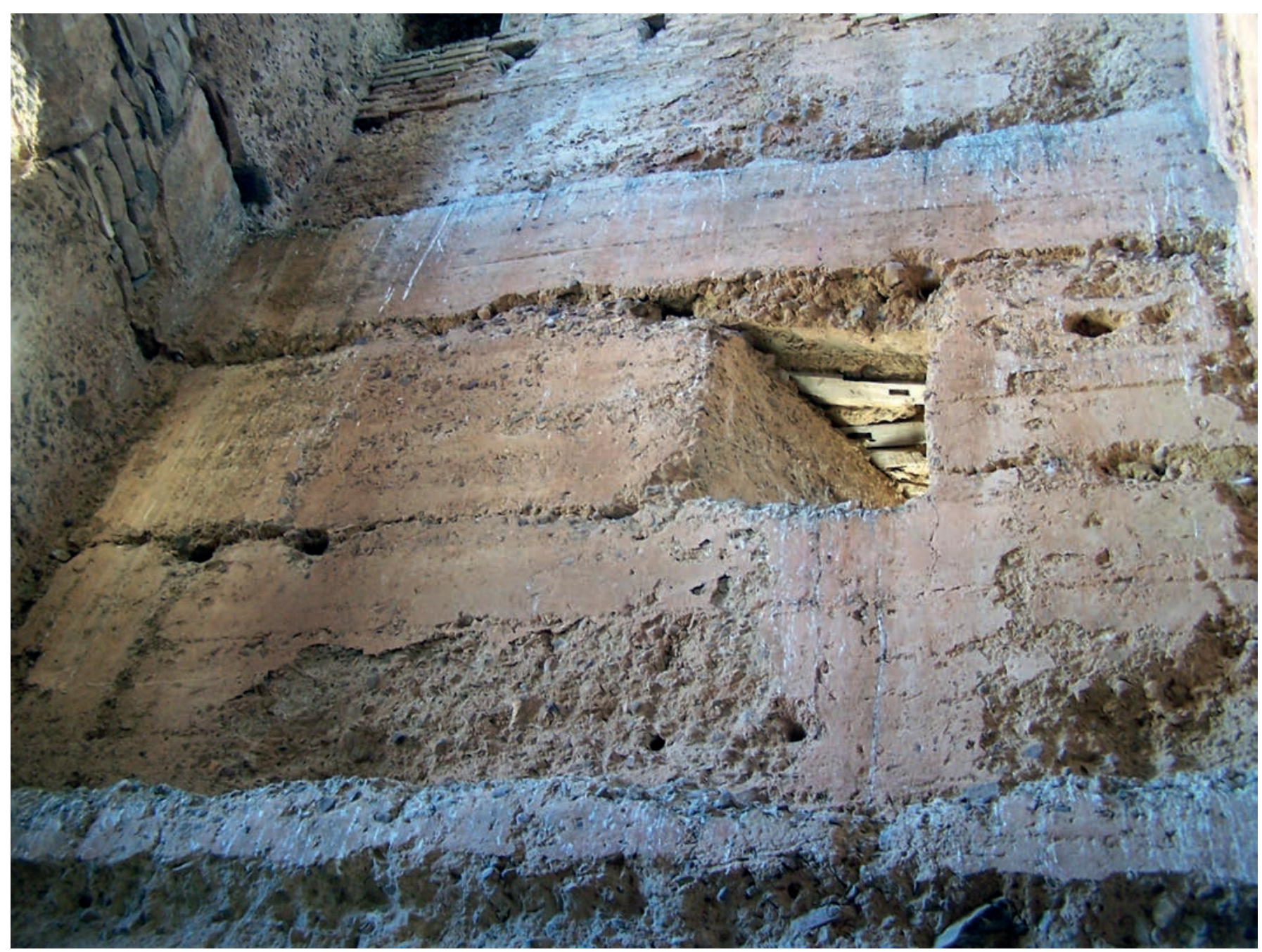

Figura 17. Interior de una de las torres del castillo de Baños de la Encina, en el que se aprecia la reutilización de agujas de encofrado a modo de dintel de la saetera.

capa de mortero calizo en la que se marca un encintado con incisiones en su interior (García Granados 2014: 488-489 y 492, Fig. 4). Las líneas que definen tales fajas también se trazarán incisas, formando una suerte de aparejo monumental fingido, de manera que las bandas horizontales coincidan con las líneas de las cabezas serradas de las agujas de cada hilada de la obra encofrada (Fig. 20). El empleo de las incisiones en el interior de las cintas debe estar relacionado con la intención de crear un "gris óptico" que permita distinguir una tonalidad más oscura que la aparente de la propia jabelga blanquecina. Desde luego, sin la presencia de tal abujardado la percepción del encintado a cierta distancia no sería posible solamente con las líneas finas que delimitan las propias cintas.

De nuevo en Granada, concretamente en la alcazaba de la Alhambra, se localiza una variante sobre la tipología anteriormente descrita, pero con una concepción más económica en cuanto a la cantidad de mortero calizo empleada. Pues en este caso, la aplicación del mortero se reduce a poco más que el espacio del encintado que, por otra parte, se seguirá delimitando mediante líneas incisas y rellenando por las mismas incisiones menudas (Fig. 21). El criterio aplicado ahora supone la optimización de la protección de la obra encofrada, extendiendo el mortero sobre las líneas de de las cabezas de las agujas para protegerlas de la putrefacción. Las cintas verticales protegerían las juntas constructivas, de haberlas; pero en el caso de encofrados continuos serían meramente estéticas. Siendo este planteamiento una evolución o mejora del anterior, adquiere sentido el marco cronológico propuesto por el autor que lo ha identificado, en el s. XII (García Granados 2014: 487, 489 y 496, Figs. 12 y 13). 


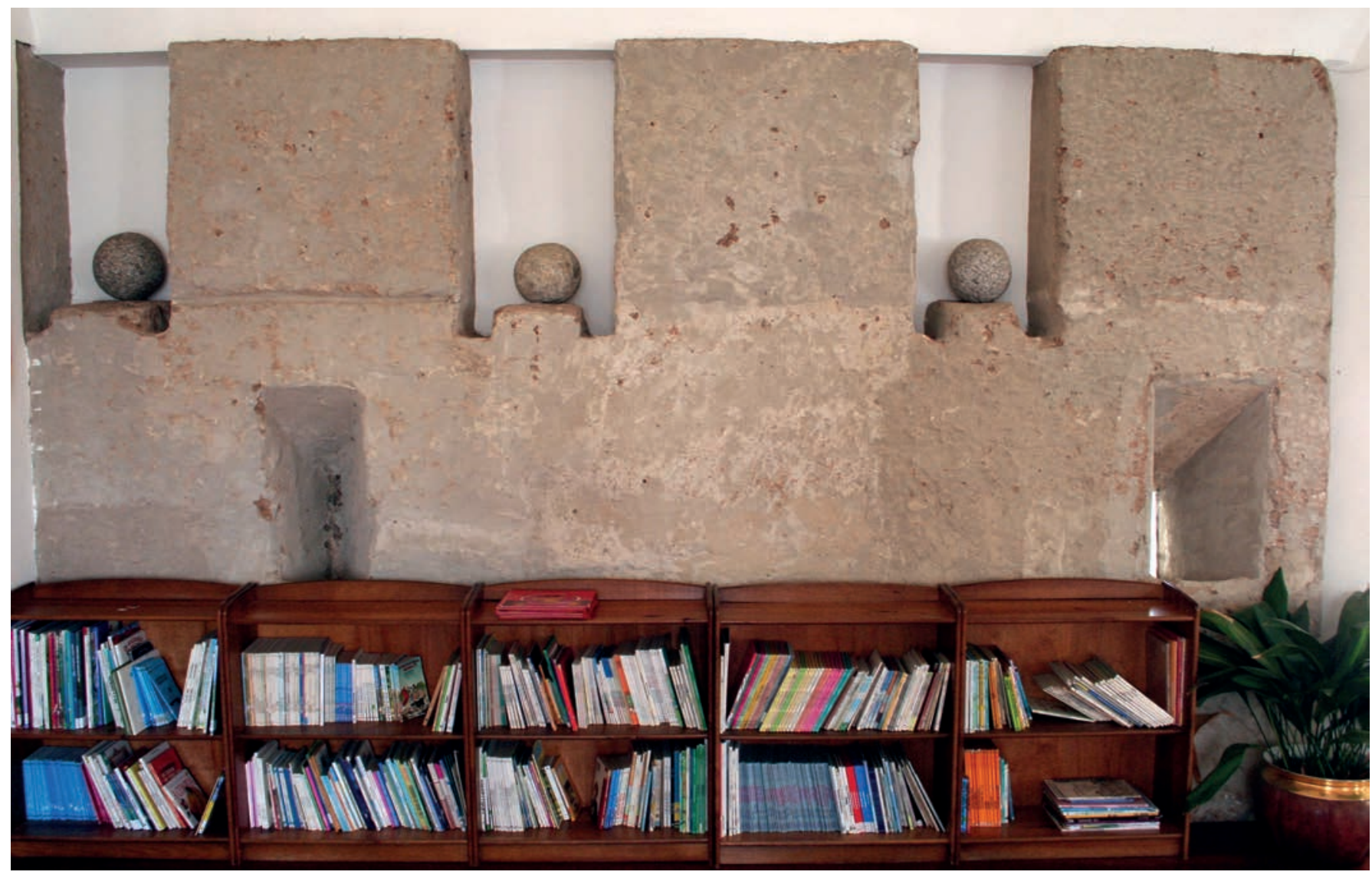

Figura 18. Pretil y merlatura de la muralla almohade de Elvas, con saeteras de molde completamente recuperable.

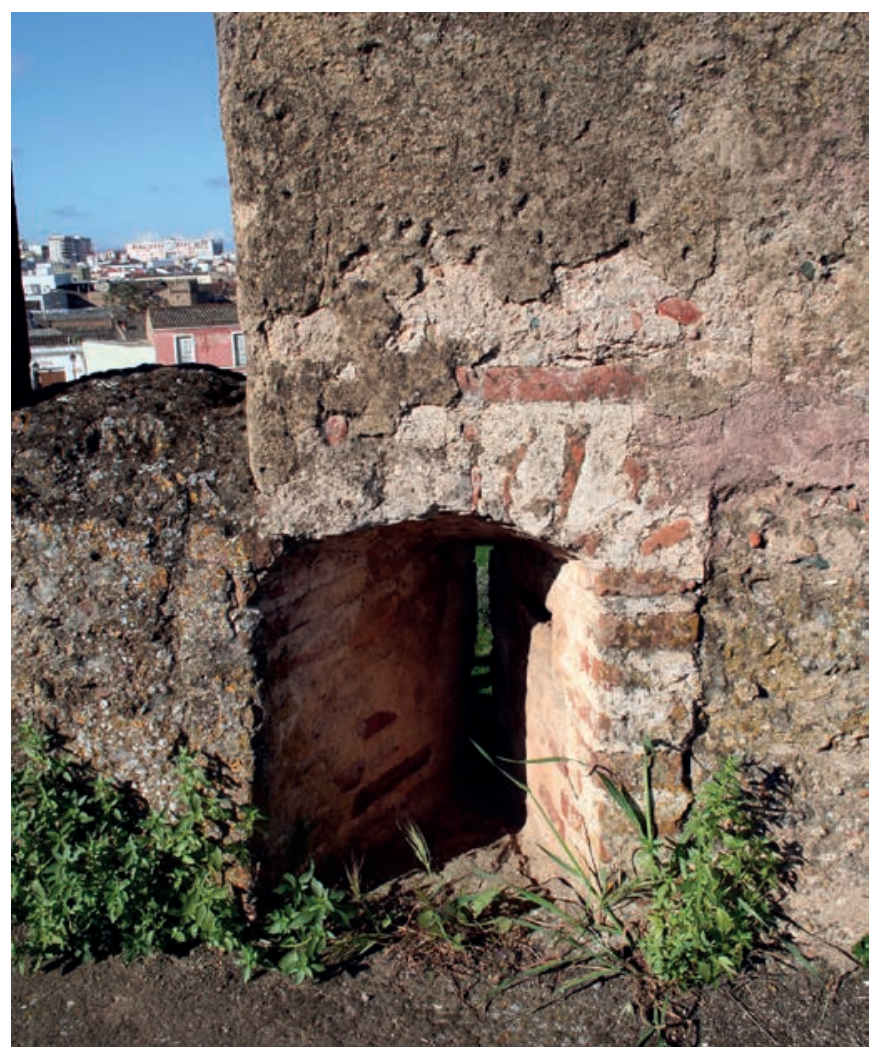

Figura 19. Saetera almohade de obra latericia en la Alcazaba de Badajoz. 


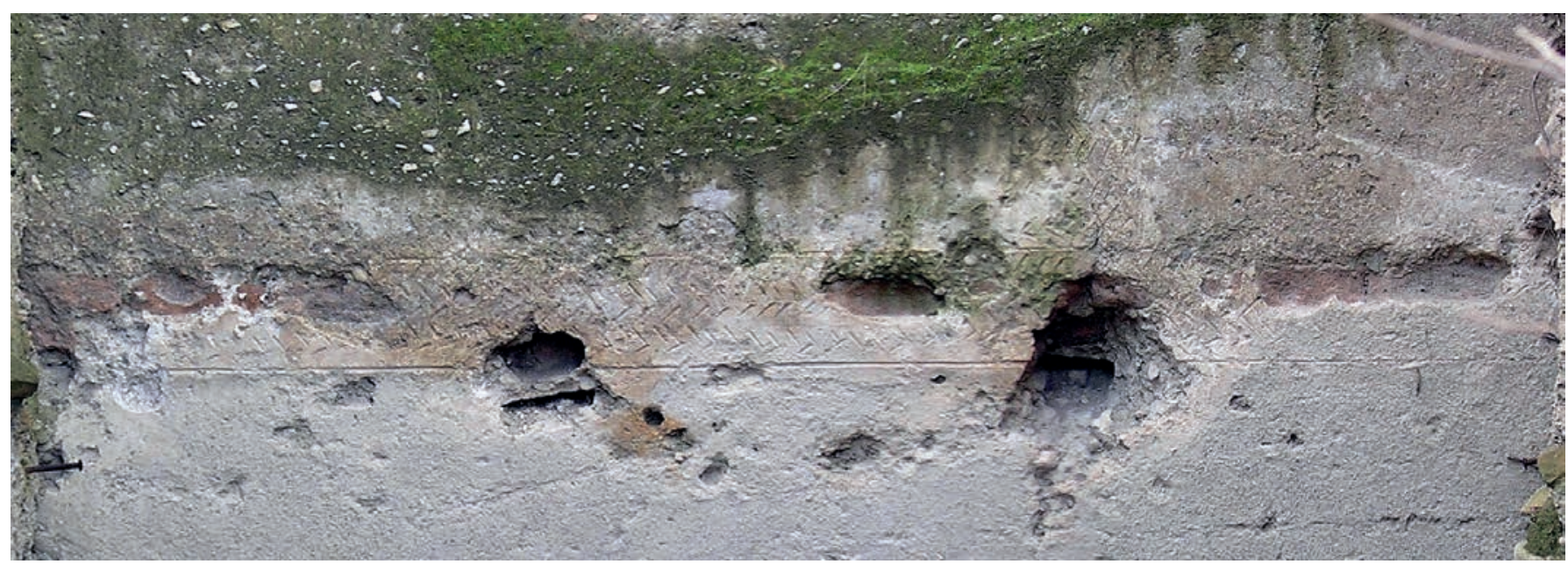

Figura 20. Encintado con incisiones, marcado sobre la jabelga de una torre taifa de las murallas de Granada. Fotografía cedida por cortesía de Juan Antonio García Granados.

El siguiente eslabón sería a su vez una depuración del precedente, en el que las líneas incisas desaparecerían de tales fajeados. El resultado mostraría ya el prototípico acabado epidérmico atribuido de manera generalizada a las obras de época almohade (Figs. 7, 8, 13, 14 y 22) ${ }^{28}$. Llegados a este punto, la primitiva función profiláctica del encintado dará paso en algunas ocasiones a una meramente de exorno, al desajustarse la coincidencia entre las cintas horizontales y la línea de las agujas del encofrado, que dejan de estar protegidas (Figs. 7 y 8). Abundando en la función estética, con el tiempo se irá acentuando este carácter mediante la combinación de cintas que abandonan la mera disposición ortogonal, dando paso a otras formas geométricas e incluso epigráficas, cuyos ejemplos más destacados se documentan en la Torre de los Pozos, en Cáceres, hacia finales de la última década del s. XII (Márquez y Gurriarán 2003: 90-93, 101; 2006: 71-82, 88; 2008: 119-120; 2013: 675-676; 2016: 58-63).

Incluso, se llegará al extremo de ejecutar encintados parciales, que pondrán en evidencia su cometido predominantemente ornamental, tal y como se aprecia en la Torre Bofilla erigida en la segunda década del s. XIII ${ }^{29}$, en Bétera, provincia de Valencia; en la que

\footnotetext{
28 El estudio de los encintados almohades se aborda en Azuar et al. (1994), Azuar (2005), Gurriarán y Sáez (2002), Márquez y Gurriarán (2003: 96-97; 2006: 49-62; 2008: 117-121), Azuar y Ferreira (2014: 403-405), y Villalba (2015: 64).

29 Mileto y Vegas (2011: 96) confirman tal cronología tras una intervención arqueológica. Previamente Azuar et al. (1994: 484) proponían una datación congruente, aunque más amplia, que abarcaba entre la segunda mitad del siglo XII y la primera mitad del siguiente.
}

únicamente se aplicaban en las hiladas inferiores y cimeras del edificio, mostrándose desnudas las centrales (Fig. 23). Finalmente, y ciñéndonos estrictamente a los encintados típicos que delimitan rectángulos, también se verán afectados por novedades ornamentales como la transformación de las cintas verticales en columnillas con cimacios que se documentan en la misma torre (Figs. 23 y 24). Como en este caso, pueden volver las incisiones en las cintas, pero bajo unas circunstancias muy concretas y realmente excepcionales ${ }^{30}$; o emplazarse otros trazados auxiliares según se aprecia en Cáceres o Alcalá de Xivert ${ }^{31}$.

No obstante, en este proceso evolutivo aparentemente lineal y progresivo, se podrían objetar ciertos

\footnotetext{
30 En la cara oeste de la Torre Bofilla se aprecia una costra de mortero calizo de bordes irregulares inmediatamente por debajo de la zona en que se emplazan unos encintados del mismo material (Fig. 24). En dicha costra se marcan otra cinta horizontal y una vertical más estrecha, rellenas con pequeñas incisiones diagonales tal y como se ha documentado en las obras de época taifa (vid supra). En las cintas superiores sobre la tapia desnuda, como es habitual en época almohade, no sería necesario tal abujardado por el propio contraste cromático entre las blancas fajas y la tapia anaranjada. No obstante, se ejecutan también pequeñas incisiones sobre el encintado superior para mantener una coherencia estética con las cintas realizadas sobre la costra en la que sí son necesarias para su percepción visual. Mileto y Vegas (2011: 96) califican tales incisiones en esta torre como "rayitas decorativas". En Mileto y Vegas (2010: 61, Plano L6) se documenta formalmente dicho encintado, pero no se hace ninguna lectura del material de soporte; ignorándose la presencia y límites de la costra caliza inferior sobre la que se traza parte del fajeado.

31 El caso Cacereño se analiza en Márquez y Gurriarán (2003: 92, 118, Lám. 9; 2006: 81, Lám. 52 y 82). En el muro de Alafia del Castillo de Alcalá de Xivert se practicaron líneas incisas longitudinales en las cintas. En cuanto a la cronología, en este caso se propone un impreciso siglo XII. Véase en Hofbauerová y de Antonio (2001: 78, Fig. 7 y 79). No obstante se concretaría la pertenencia al período almohade en Azuar (2005: 125), y Azuar y Ferreira (2014: 403). Incluso en Azuar et al. (1994: 484) se proponen fechas oscilantes entre finales del siglo XII y principios del siguiente.
} 


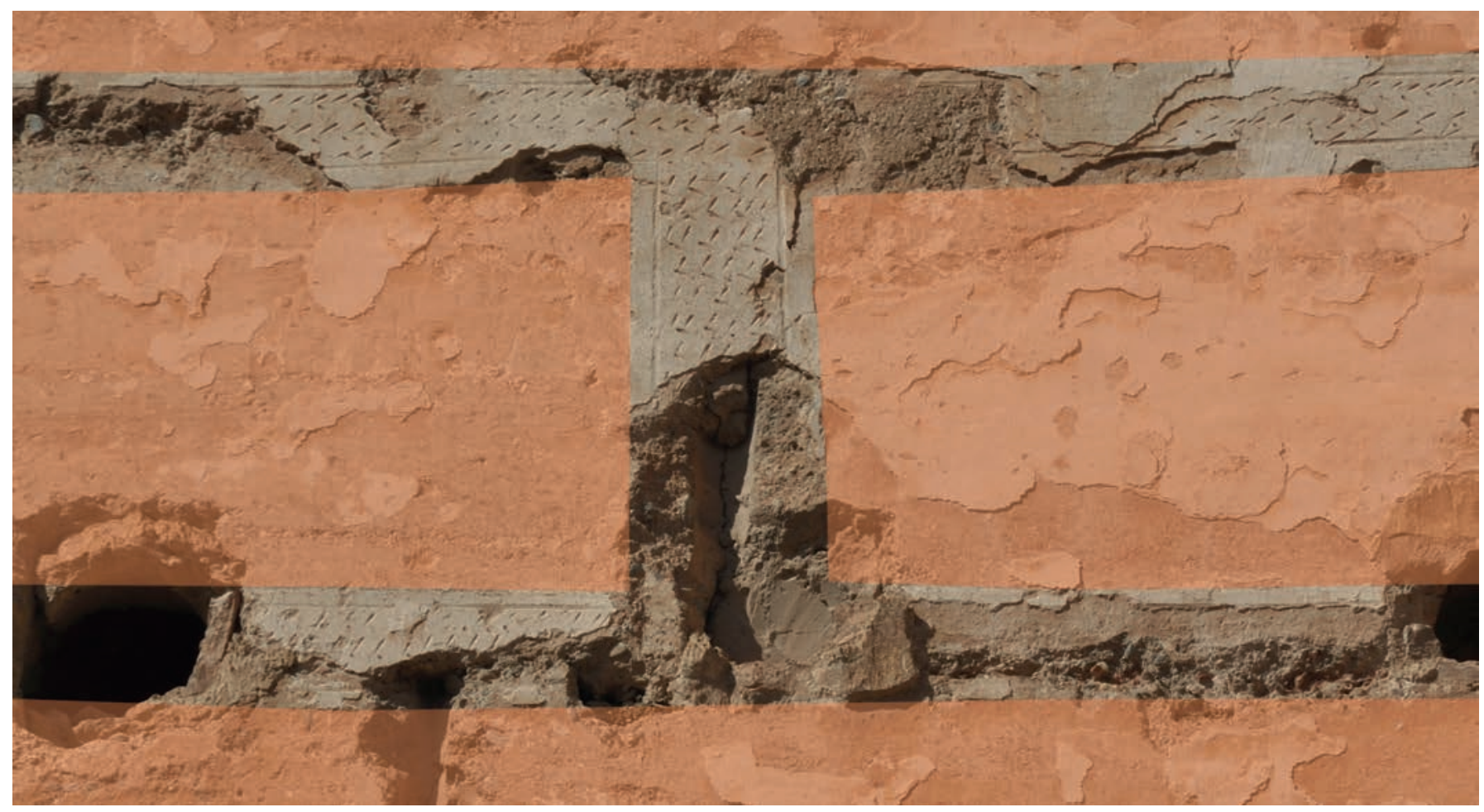

Figura 21. Encintado con incisiones, marcado sobre fajas de mortero calizo dispuestas sobre la superficie de las tapias, en la alcazaba de la Alhambra. Fotografía cedida por cortesía de Juan Antonio García Granados, y posteriormente manipulada para poner en evidencia la epidermis desnuda de la obra encofrada; actualmente deteriorada y parcheada por restos sucesivos de jabelgas.

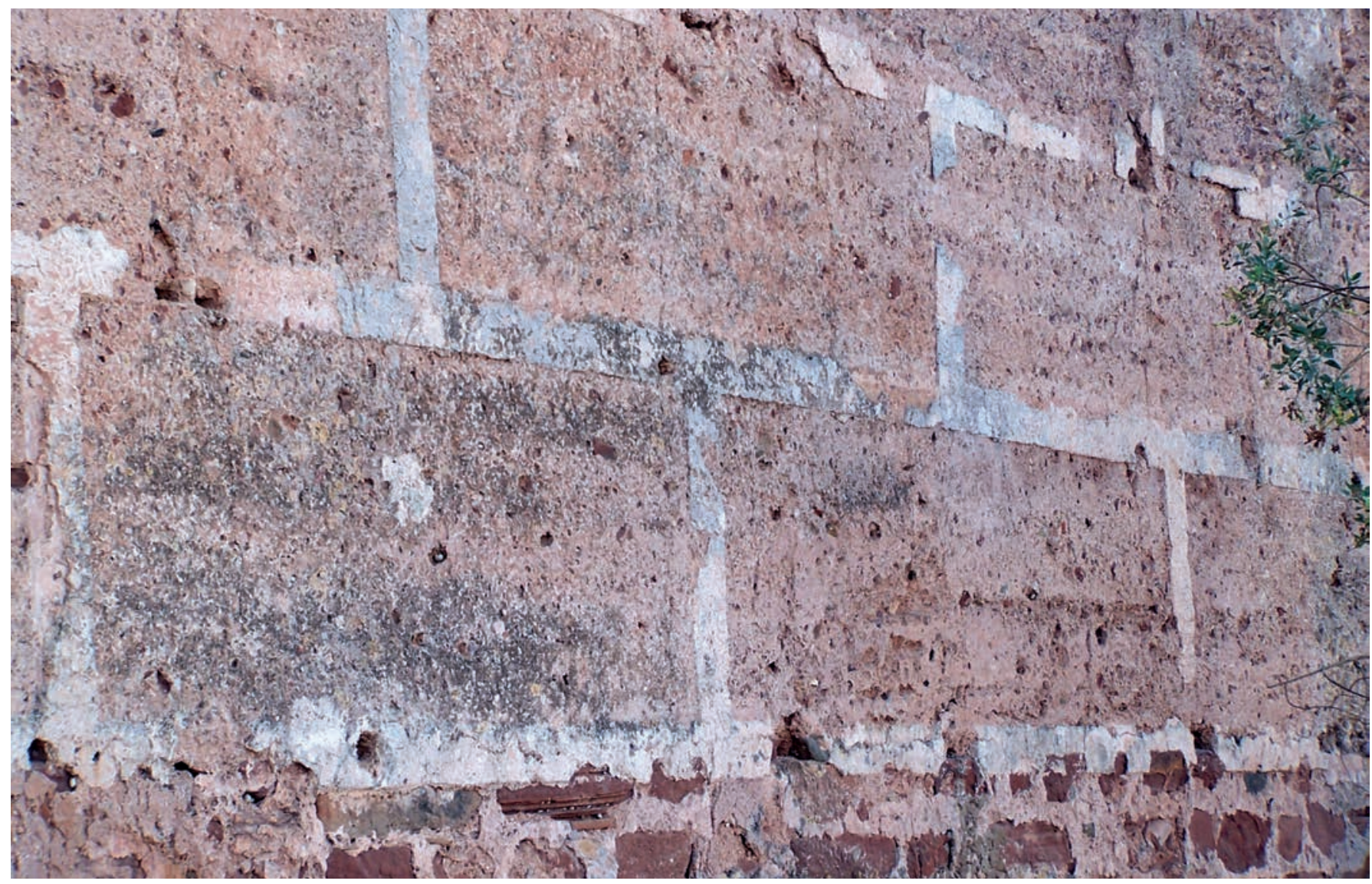

Figura 22. Clásico encintado almohade en los muros septentrionales del recinto urbano de Silves. 


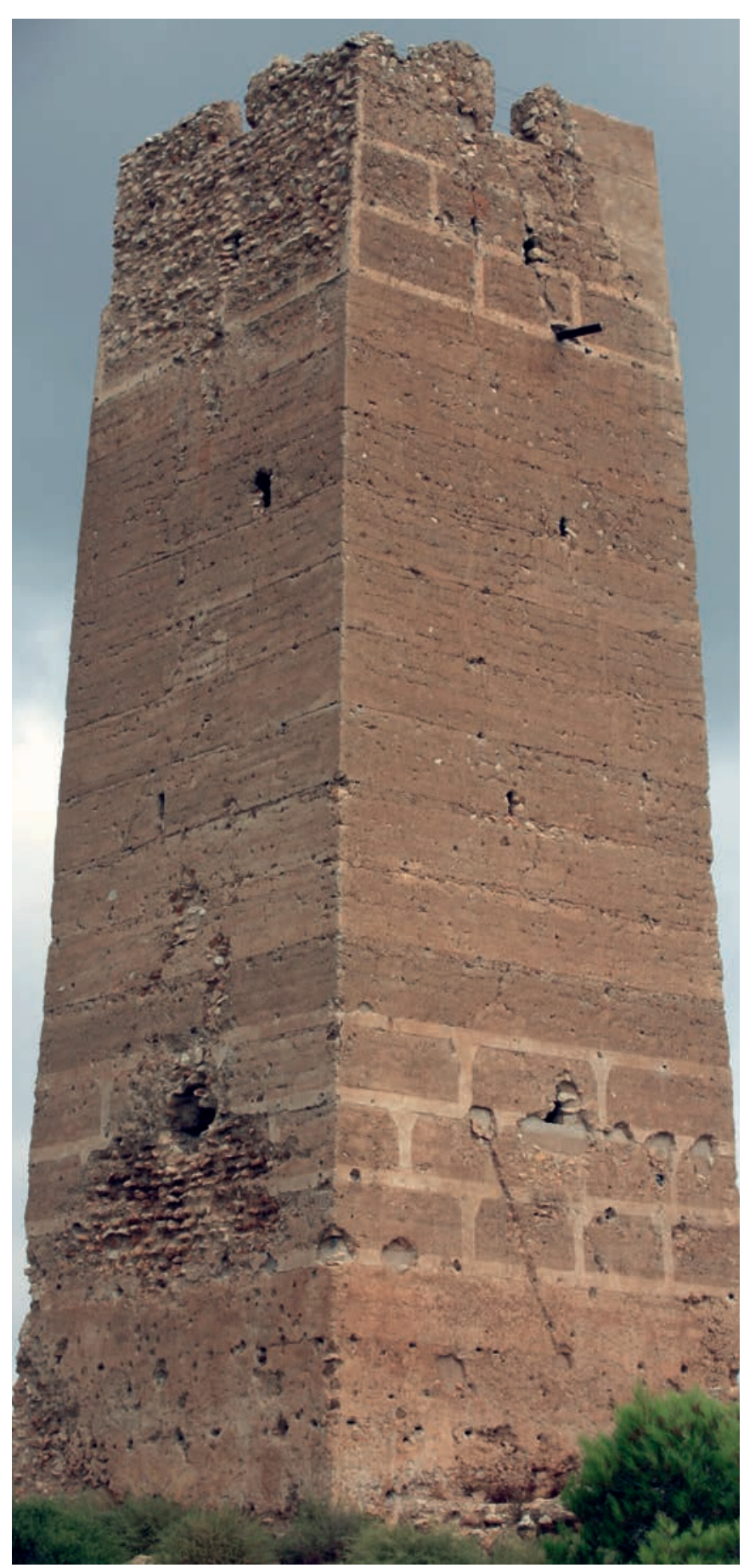

Figura 23. Caras sur y este de la Torre Bofilla. La limpia y absoluta ausencia de encintados en el tramo central del prisma, revela que únicamente fueron encintadas la base y coronación de la construcción.

"peros" o contradicciones. En el castillo de Baños de la Encina se documentan unos encintados que siguen el esquema de los más primitivos de época taifa, aquellos que se disponían incisos sobre una jabelga que cubría por completo la superficie de las torres. En este caso, además cuentan con una serie de variantes ornamentales que superan ese planteamiento básico descrito para los ejemplos granadinos ${ }^{32}$ (Fig. 25). Los últimos estudios arqueológicos sobre esta fortificación jiennense asumen claramente su paternidad muminí (vid supra). Así, dado el evidente contraste entre el tipo de acabados superficiales constatado de manera prácticamente sistemática en las fortificaciones de los Unitarios y el que aparece en este recinto; se plantearía, más que una extraña involución, la no asunción automática de las sucesivas novedades en la evolución de los tratamientos epidérmicos. Dentro del amplio arco temporal almohade en al-Ándalus (1147-1228) podría sugerirse una cronología temprana para Baños de la Encina, o incluso volver a revisar la adscripción a tal período. De hecho, la cercana fortaleza de las Navas de Tolosa ostenta el mismo tratamiento en los paramentos de su torre exagonal, en este caso con la misma sencillez que los ejemplos taifa granadinos, y ha sido encuadrada en un extenso período almorávide-almohade ${ }^{33}$. En cualquier caso, estas obras de los castillos de Baños de la Encina y las Navas de Tolosa, parecen sincrónicas, tanto por la similar concepción en cuanto a soluciones epidérmicas como constructivas ${ }^{34}$.

En definitiva, lo que sí quedaría demostrado es la transformación coherente de estos tratamientos superficiales en obras encofradas entre las taifas y los almohades, por lo que podrían fijarse unos hitos evolutivos al margen de la disputa de la afinación de las atribuciones cronológicas (Fig. 27).

Finalmente, cabe recordar que si bien es cierto que los típicos encintados almohades siempre daban paso a una jabelga perfectamente perfilada en pretil y merlatura, e incluso en varias hiladas superiores en casos

\footnotetext{
32 Ferrer (1996: 7-10) describe los vestigios de decoración más visibles en Baños de la Encina y realiza calcos parciales de los mismos; aunque los encuadra en el s. X, según las ideas predominantes todavía en los años 90. Pavón (1999: 692, Fig. 6) recoge encintados con incisiones sobre jabelga completa, en la Alcazaba de Guadix, que también se salen del patrón habitual; en este caso fechados de manera un tanto inconcreta entre los siglos XI y XII. 33 La cronología califal propuesta por Torres (1957: 647-648) ha sido desechada por Eslava (1999: 98) y Gozalves y Gozalves (2014: 549), que han gozado de una perspectiva mayor por los avances generales en el conocimiento de la arquitectura andalusí. Por desgracia, no podemos contar con otras opiniones, dado el escaso interés que ha suscitado esta fortificación. 34 En ambas fortalezas se aprecia el mismo pequeño pero revelador detalle constructivo que indica la posible coincidencia de cuadrillas de albañiles. No es otro que las parejas de orificios que tachonan las líneas de las agujas, generados por su putrefacción. La peculiar disposición de las agujas, más remetidas, no es habitual en otros casos (Figs. 25 y 26).
} 


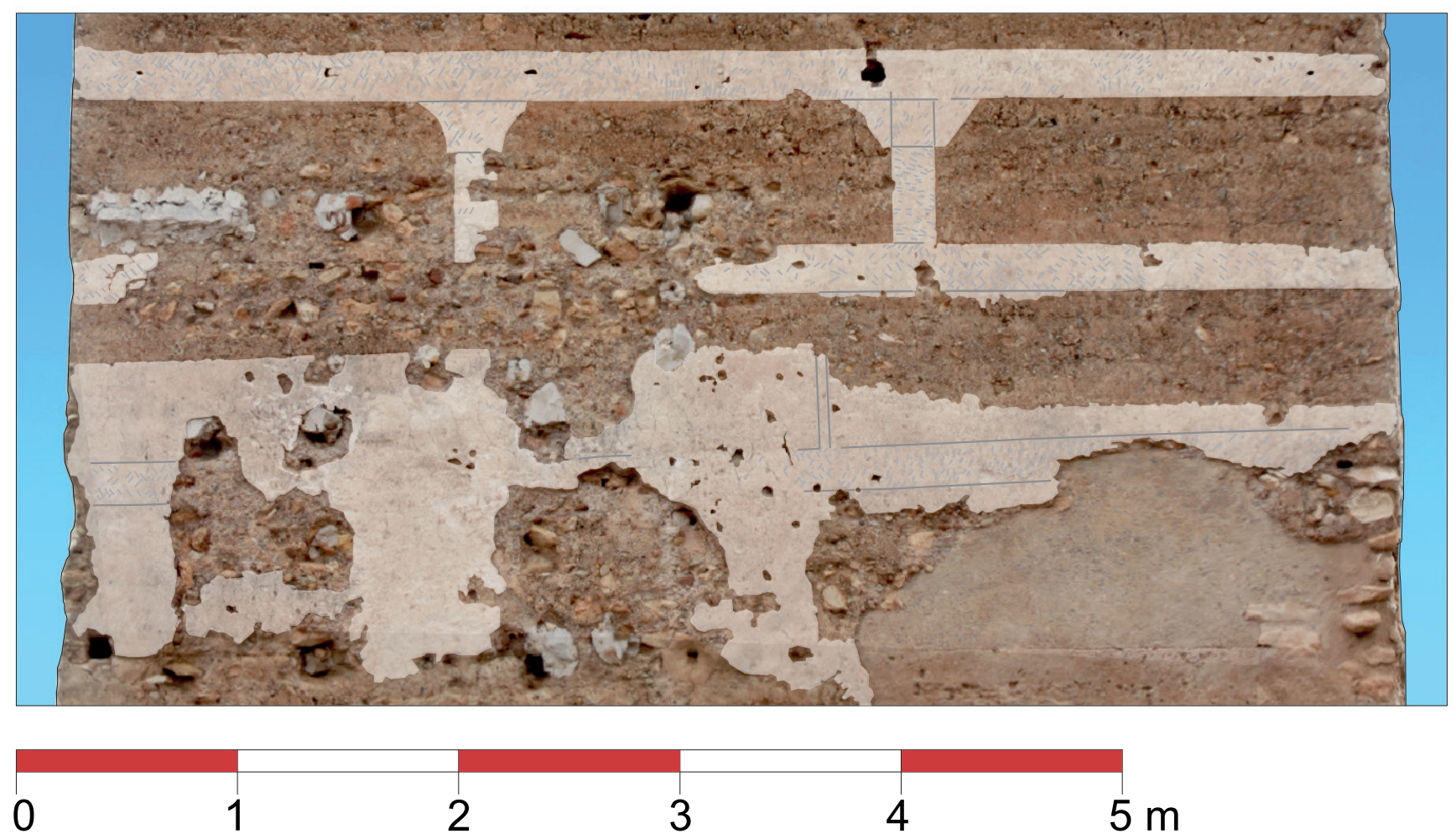

Figura 24. Ortoalzado, de nube de puntos, realizado con la colaboración de Pedro Gurriarán Daza; del detalle de la base de la cara oeste de la Torre Bofilla. Se ha magnificado la presencia del mortero calizo superficial, así como de las líneas incisas.

concretos $^{35}$; en ciertas ocasiones, la totalidad de la torre o lienzo quedará cubierta por el mortero calizo, carente de cualquier labor de exorno ${ }^{36}$ (Figs. 28, 29 y 30).

\section{LAS IMPOSTAS DOBLES DE LAS TORRES}

Merece la pena detenerse en un elemento ornamental, tradicionalmente asociado a torres del bajo Guadalquivir, como es la pareja de impostas que suelen ostentar numerosas torres en su parte superior. No

\footnotetext{
35 Márquez y Gurriarán (2003: 96; 2006: 50-60; 2008: 118-119) describen y analizan este canónico remate epidérmico cimero; mientras que la variante poco común con mayor presencia de mortero en la parte superior de las torres, vista en Niebla y la Torre de los Pozos de Cáceres, se trata en Márquez y Gurriarán (2006: 58 y 74-76, Láms. 47 y 48).

36 Jiménez y Pérez (2012: 289) revisan las intervenciones arqueológicas en que se ha documentado jabelgas, presumiblemente originales, en la cerca hispalense. Por citar otros recintos, en los castillos de Giribaile, en Jaén, o el mencionado de Monteagudo, se aprecian amplias porciones de jabelgas, presumiblemente originales, completamente lisas. En concreto, las tapias enjalbegadas de Giribaile se han podido adscribir fehacientemente al período almohade mediante análisis radiocarbónico. Véase en Castillo, Gutiérrez y Gutiérrez (2010: 251-253).
}

obstante, el origen formal de esta práctica pudiera tener sus antecedentes en los cordones, simples y triples registrados en la zona más elevada de lienzos y torres de fortificaciones omeyas del entorno del Estrecho $^{37}$. Ya en Sevilla, y concretamente en su alcázar, se documenta en su forma habitual de cordón o imposta doble en los remates cimeros de su primitiva portada $\mathrm{y}$ torres del primer recinto, erigidas respectivamente entre finales del s. XI y principios del s. XII, y en los inicios del s. XII (Tabales y Vargas 2014: 17-21). En el primer caso, se formalizarían mediante sillares, al igual que las obras omeyas precedentes, y en el segundo en ladrillo.

En varias torres de la cerca sevillana, una pareja de estas verdugadas ciñe las saeteras que se abren desde el interior de la cámara, de modo que tales elementos funcionalmente coherentes quedarían relacionados en un mismo momento constructivo (Fig. 29A). Si la historiografía está de acuerdo unánimemente en que el recrecido de dos cajones que

\footnotetext{
37 Consúltense los casos de Tarifa y Ceuta, en Gurriarán (2001: 167-168) e Hita y Villada (2004: 42), respectivamente.
} 

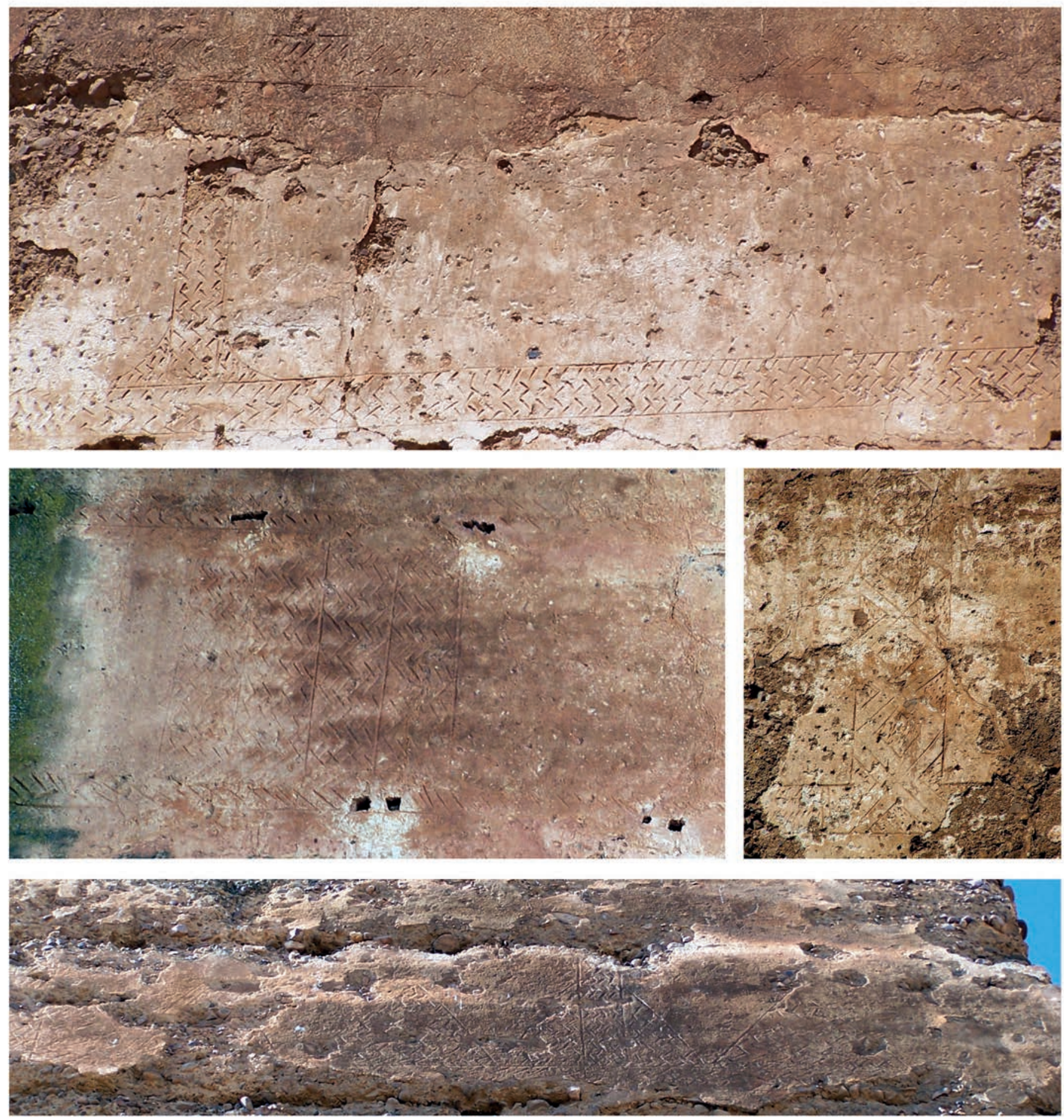

Figura 25. Distintos ejemplos de decoración incisa en el mortero original de torres y lienzos del recinto de Baños de la Encina. 


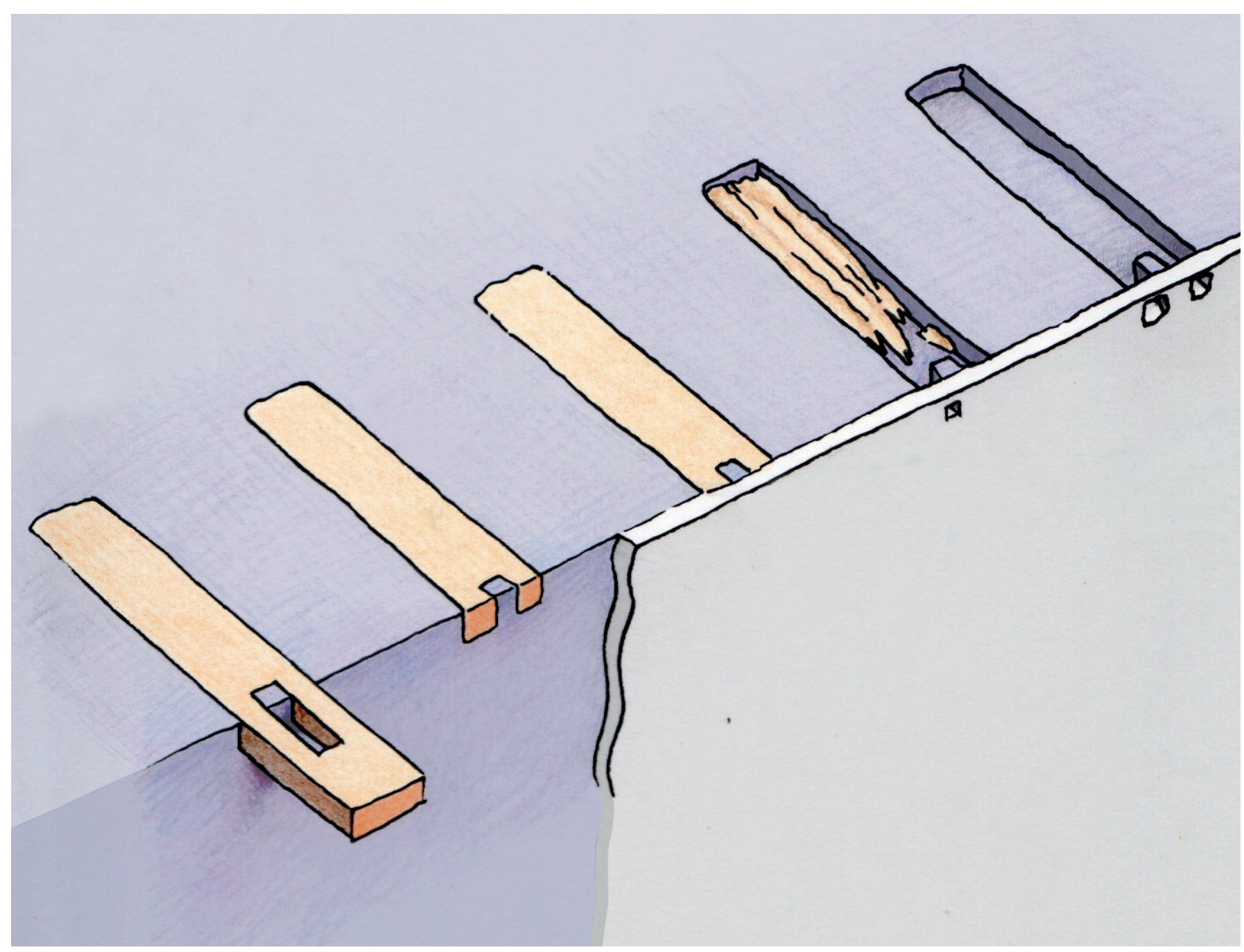

Figura 26. Croquis del proceso de degradación de las agujas y posterior aparición de orificios pareados en la jabelga de los tapias de las fortalezas de Baños de la Encina y las Navas de Tolosa.

se aprecia a lo largo de la muralla pertenece a las reformas de $1221^{38}$, las cámaras accesibles desde el adarve resultante, y por ende los resaltos exteriores, también serían adscribibles a esa fecha (Jiménez 1996: 22; Jiménez y Pérez 2012: 293-294 y 297). Por otra parte, torres almohades de los recintos de Écija y Marchena que ostentan tales impostas latericias han sido fechadas ya en el s. XIII ${ }^{39}$. A esto debemos añadir que Badajoz también fue objeto de una campaña

\footnotetext{
38 Tanto el recrecimiento general de la muralla como la erección del antemuro se relacionan con las menciones de Ibn Abi Zar (1964: 523). Véase también en Jiménez y Pérez (2016: 20). Sin embargo, en el tramo de muralla de la calle del Agua, el recrecido debió realizarse bastante antes, hacia 1172. Véase en Jiménez Martín (2007: 29).

39 Valor (2004: 152) menciona las albarranas de Écija, con verdugadas, como añadidos del s. XIII. Bellido (2008: 181) refiere que las defensas almohades de Marchena fueron levantadas ex novo en el primer cuarto del s. XIII.
}

de obras a principios de esa centuria, de una envergadura aún no aquilatada, cuyos indicios apuntan a que debió de ser de gran magnitud (Márquez y Gurriarán 2012: 72). Por todo ello, nos atrevemos a sugerir que este tipo de recurso constructivo parece proliferar realmente a partir de un momento ciertamente tardío, dentro del período almohade.

Incluso, en algunas torres del recinto urbano hispalense sus verdugadas se unen a bandas verticales del mismo material, lo que supone una evolución en relación con la típica distribución de impostas estrictamente horizontales. Esta cuestión adquiere sentido si además una de esas torres es claramente posterior a las anteriormente referidas del mismo recinto, como la llamada Torre Blanca, de planta octogonal irregular. Si nos guiamos por la tradicional filiación almohade 

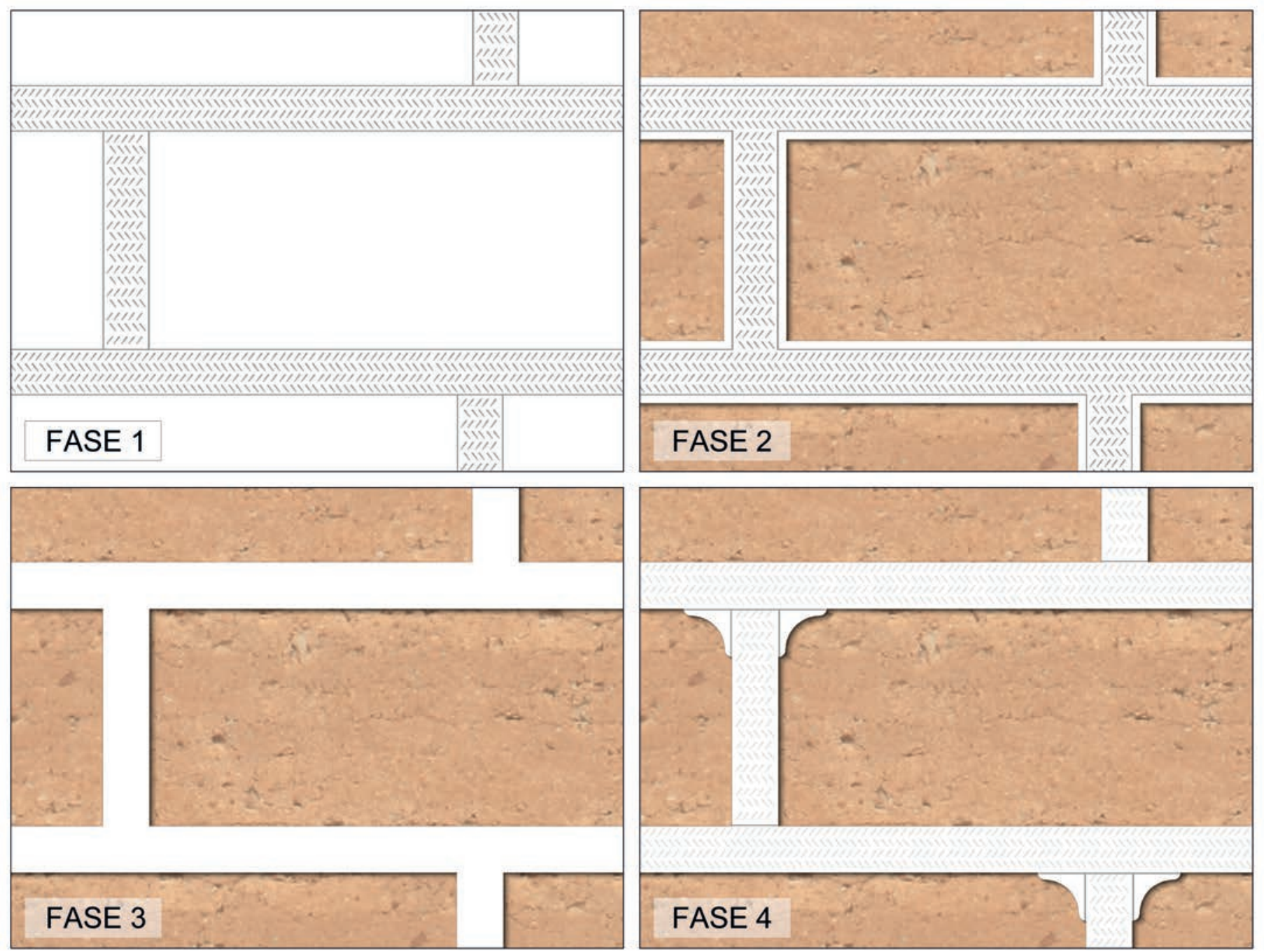

Figura 27. Esquema de la evolución de los encintados desde las taifas hasta finales del período almohade. Fase 1: encintado con incisiones sobre jabelga completa. Fase 2: encintado calizo sobre tapia desnuda, con incisiones. Fase 3: encintado calizo sobre tapia desnuda. Fase 4: encintado calizo sobre tapia desnuda, con formalizaciones más complejas de carácter geométrico, epigráfico y arquitectónico. Bajo circunstancias concretas pueden volver las incisiones sobre el mortero calizo.

de esta construcción, habría sido erigida entre $1221 \mathrm{y}$ 1248, año de la conquista cristiana de Sevilla ${ }^{40}$ (Fig. 29B). No obstante, tampoco se puede descartar una cronología posterior a $1248^{41}$. Las otras torres cuadrangulares que ostentan semejante tipo de resaltos latericios podrían encuadrarse en ese mismo impulso

\footnotetext{
40 Todos los autores consultados le atribuyen una paternidad almohade, ya sea por alusión u omisión. Véase en Pavón (1999: 336), Valor (2004: 150), Villalba (2015: 187), y Jiménez y Pérez (2015: 59) y (2016: 24). Por otra parte, Valor (2008: 42) opina acertadamente que la Torre Blanca, es un añadido posterior al antemuro levantado en 1221, según recoge Ibn Abi Zar (1964: 523). Para ello arguye la escasa distancia entre la torre y el antemuro, como si ésta se hubiera encajado en un hueco preexistente. Otro argumento a favor es que dicho antemuro se dispone de forma trapezoide, en planta, a los pies de cualquier torre cuadrangular; y al pasar junto a la Torre Blanca conserva ese trazado en vez de amoldarse a la torre octogonal irregular que debió suplantar o forrar una cuadrangular.
}

\footnotetext{
${ }^{41}$ A Daniel Jiménez Maqueda, viva vox, le debo y agradezco la reflexión sobre la desastrosa coyuntura política en Sevilla, después de 1228, que deja un margen de unos siete años en los que pudo haber sido erigida una obra de la magnitud de Torre Blanca, de manera plausible. Por otra parte, la sofisticación de los elementos ornamentales, y ciertas peculiaridades en la disposición entre las cámaras y el pasillo de ronda, delatan una concepción muy tardía de la obra. Por no hablar de las recientes dudas planteadas por Domínguez (2008: 243-244) y Amores (2014: 31, nota 41) acerca de las torres poligonales de la Plata y Abdelaziz, que bien pudieran "arrastrar" a la Torre Blanca, al poner en tela de juicio el horizonte andalusí en las reformas medievales significativas en el recinto amurallado hispalense.
} 


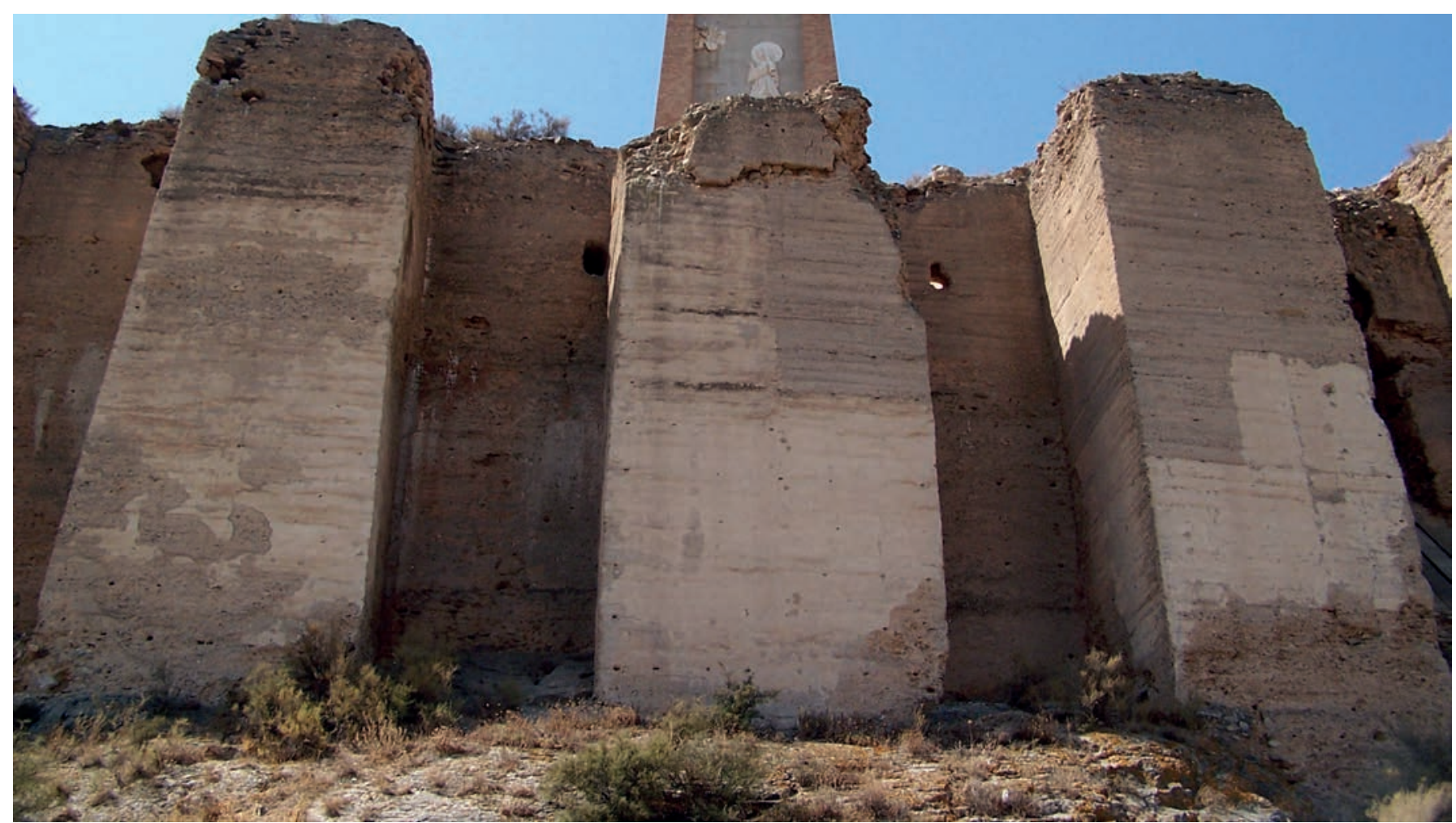

Figura 28. Torres con vestigios originales de jabelga, en el Castillo de Monteagudo. Obsérvese la disposición de los tapiales según lo indicado en la figura 14.

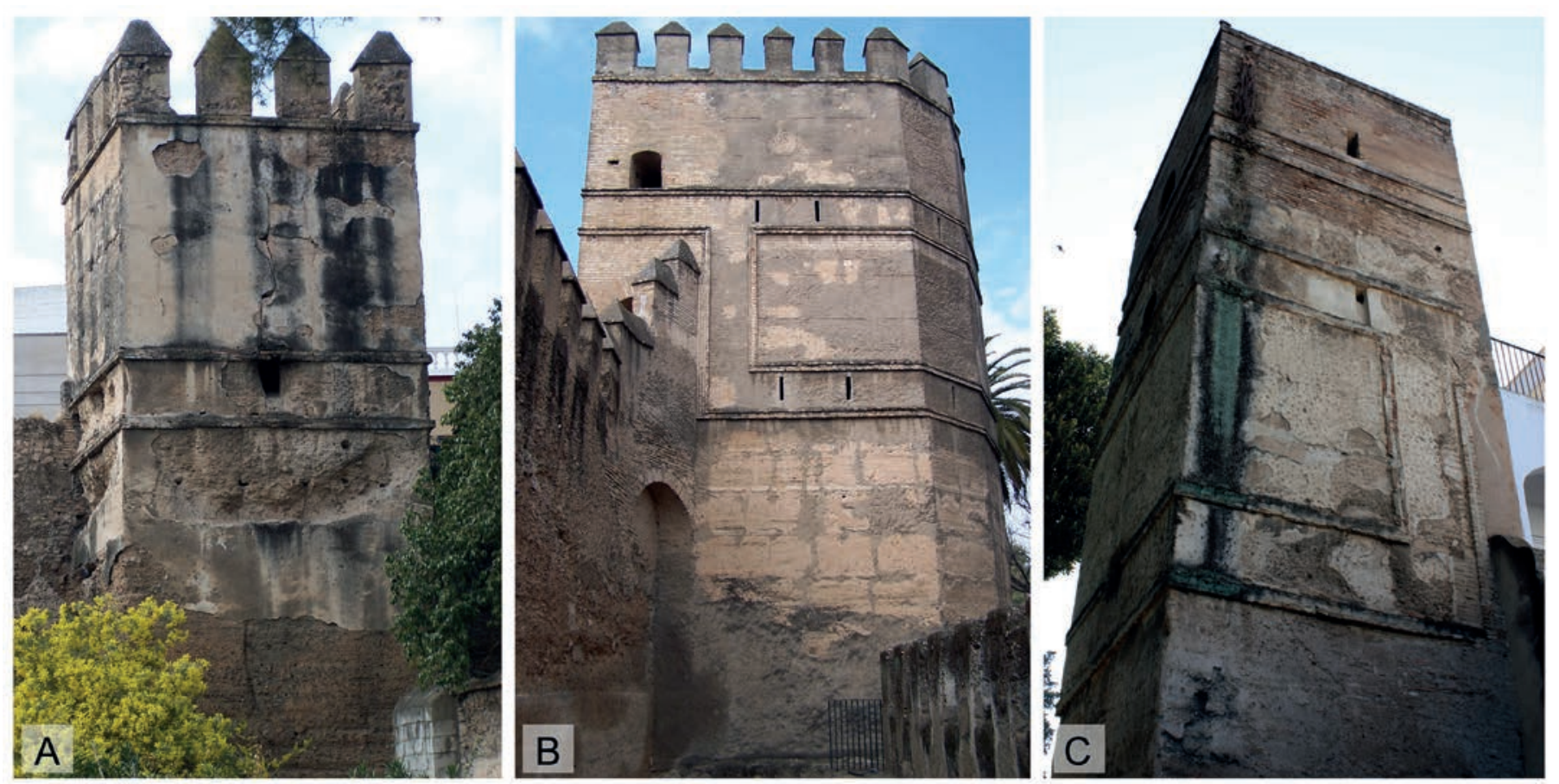

Figura 29. Torres ampliadas o construidas en período almohade, o posterior, en la cerca urbana de Sevilla. A: Torre próxima a la Puerta de Córdoba, con vestigios de jabelga; aunque todavía no se ha constatado que se trate de la original. B: Torre Blanca. Desde la base hasta la primera imposta estaba encintada. De ahí hasta su coronación estaría completamente enjalbegada, como delata su nombre. C: Torre en los Jardines de Murillo, con restos del mortero calizo superficial; no obstante, sujeto a la comprobación de su origen. 


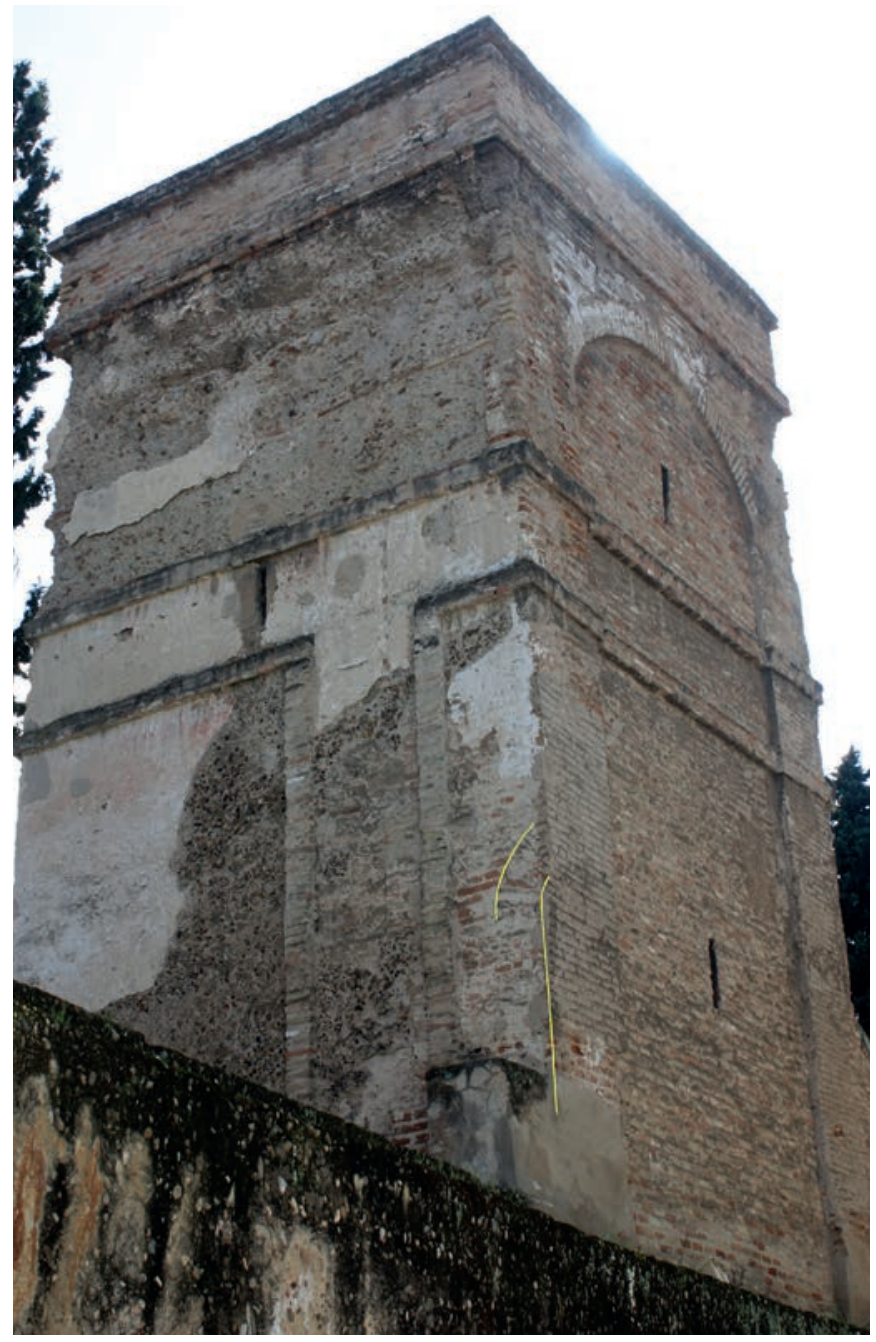

Figura 30. Torre de la calle del Agua, en Sevilla. Se ha marcado en amarillo la huella del arco mutilado de paso del adarve. Compárese con la figura 29B.

edilicio, ya sea tardoalmohade o cristiano $^{42}$ (Figs. 29C y 30$)$.

En resumidas cuentas, todo parece indicar que, tras unos titubeos previos, la aparición de estas bandas en su disposición más común tendrá lugar en el Alcázar de Sevilla en torno a la transición entre los siglos XI y XII. Posteriormente, y ya ejecutadas habitualmente en ladrillo, su proliferación en la propia capital, bajo

\footnotetext{
42 Tabales (2002: 114) propone que al menos una de estas torres, la contigua a la calle del Agua, pudo haber sido erigida a comienzos del s. XIII. Por otra parte, originariamente debieron mostrar mayores semejanzas formales con la Torre Blanca; pues al igual que ésta, aquellas invadían el espacio del adarve según delatan los restos del arco original de paso por el adarve, en la torre de la calle del Agua (Figs. 28B y 29). Además, su cara interior es claramente una refacción en la que no hay rastro alguno del acceso a las cámaras, que actualmente se efectúa por hueco abierto en un lateral de la torre. No obstante, varias torres del tipo convencional, con cámara, del tramo de Macarena, también parecen haber abarcado hasta el espacio del adarve, como las mencionadas; según se aprecia de visu. Véase también en Pozo (2008: 152; Plano 45).
}

Guadalquivir y Badajoz, como enclave aislado (Márquez y Gurriarán 2008: 132), se enmarcará entre finales del s. XII la primera mitad del s. XIII; en que evolucionará rápidamente prolongándose su difusión en la posterior arquitectura mudéjar.

\section{CONCLUSIONES}

A pesar de que las construcciones mediante encofrados se documentan desde un momento temprano en el medievo andalusí, no será hasta el s. XI en el que tendremos constancia de cierta madurez de la técnica; tras la proliferación de los procedimientos de albañilería en detrimento de los de cantería, en obras de carácter militar. Posteriormente, almorávides $\mathrm{y}$, sobre todo, almohades depurarán y estandarizarán sus procesos, erigiendo con eficacia torres en las que se combinarán encofrados masivos para las partes macizas y otros anulares y/o modulares para las cámaras. Del mismo modo, las soluciones epidérmicas de protección y ornato de la superficie de las tapias, reflejarán una progresiva economía material con la evolución de los encintados, que por otra parte desarrollarán un creciente sentido simbólico y propagandístico. También bajo los Unitarios se habrá hecho patente la progresiva incorporación de materiales auxiliares, ya evidente desde las taifas en los refuerzos angulares de las torres ${ }^{43}$. De modo que a partir de la segunda mitad del s. XII, por un lado, los forjados de madera tenderán a ser sustituidos por bóvedas de ladrillo, y por otro se irá incrementando el uso de este material en bandas resaltadas que marcan pretiles y cámaras ${ }^{44}$. No obstante, esta última cuestión será más evidente en el bajo y medio Guadalquivir, y Badajoz, como caso concreto y aislado del occidente andalusí (vid supra).

En cualquier caso, este desarrollo tecnológico y constructivo ligado al aumento del uso de ladrillo apunta a cierta economía de los materiales que intervienen en los encofrados. En el caso de las agujas, muchas se convierten en recuperables al dotarse los cajones de cobijas latericias, sobre todo en muros delgados.

La absoluta madurez, en las soluciones técnicas y formales, alcanzada bajo los muminíes, dará lugar a no pocas confusiones acerca de la filiación almohade o cristiana

\footnotetext{
43 Graciani y Tabales (2008: 155-156) ya refieren el paso de fábricas exclusivamente resueltas mediante tapias a fábricas mixtas, en el s. XI.

44 Azuar (2004: 70-71) analiza la gran eclosión del ladrillo en época almohade como material constructivo, en torno al área sevillana, y refiere su combinación con las fábricas de tapial, sobre todo en la primera mitad del s. XIII.
} 
de algunas fortificaciones. Por citar un ejemplo notable, Alcalá de Guadaíra ha sido objeto de un largo debate historiográfico en el que finalmente se ha ido aceptando que gran parte de las estructuras que en algún momento han sido consideradas como almohades, son en realidad bajomedievales (García Fitz 2008: 49-144). Tampoco podemos dejar de mencionar el caso de Palma del Río, de la que ya se ha planteado alguna duda acerca de la paternidad de gran parte del recinto, que bien podría ser posterior ${ }^{45}$. Por último, de las sevillanas y poligonales torres de la Plata y de Abdelaziz o Santo Tomás, también se ha propuesto una cronología cristiana, en detrimento de la tradicional almohade (Domínguez 2008: 243-244; Amores 2014: 31, nota 41). De cualquier manera, esto no hace más que confirmar el asiento y arraigo de unas formas y tecnología constructiva más allá del período histórico andalusí que sirve inicialmente de marco; y que abarcará hasta finales del medievo.

\section{BIBLIOGRAFÍA}

Almagro Gorbea, A. 2008: "La puerta califal del Castillo de Gormaz", Arqueología de la Arquitectura, 5, pp. 55-77.

Almagro Gorbea, A., Soler Estrella, A. y Soler Verdú, R. 2014: "La torre almohade de Villena (Bilyana) y sus bóvedas de nervios entrecruzados. Análisis formal y constructivo", Anales de Historia del Arte, 24, pp. 9-35.

Amores Carredano, F. 2014: "Revisitar la Torre del Oro de Sevilla desde la Arqueología", Archivo Hispalense, 294-296, pp. 13-39.

Azuar, R. 2004: "Técnicas constructivas y fortificación almohade en alAndalus", en M. Valor Piechotta, J. L. Villar Iglesias y J. Ramírez del Río (eds.), Los Almohades. Su patrimonio arquitectónico y arqueológico en el sur de al-Andalus, pp. 57-74. Consejería de Relaciones Institucionales de la Junta de Andalucía, Sevilla.

Azuar, R. 2005: "Aspectos simbólicos de la arquitectura militar almohade. El falso despiece de sillería y las bóvedas de arcos entrecruzados", Los Almohades: problemas y perspectivas, vol. I, pp. 123-147.

Azuar, R. et al. 1994: "El falso despiece de sillería en las fortificaciones de tapial de época almohade en al-Andalus", I Congreso de Castellología Ibérica, pp. 481-511. Palencia.

Azuar, R. y Ferreira Fernandes, I. C. 2014: "La fortificación del califato almohade", en P. Cressier y V. Salvatierra (coords.), Las Navas de Tolosa 1212-2012. Miradas cruzadas, pp. 395-420. Jaén.

Bellido Márquez, T. 2008: "Análisis estratigráfico en la muralla medieval de Marchena (Sevilla)", Arqueología de la Arquitectura, 5, pp. 159-185.

Bermúdez Cano, J. M. 2005: "La Puerta de Baeza en la cerca de la Ajerquía cordobesa", Anuario Arqueológico de Andalucía 2002, vol. 3, tomo 1, pp. 333-349.

\footnotetext{
45 Córdoba (2004: 126-128) confirma acertadamente la cronología cristiana de los accesos y siguiere una reforma bajomedieval o moderna en la parte alta de las torres. En mi opinión, las dos fases constructivas detectadas en sus lienzos, el completo adosamiento de sus torres aparentemente monofásicas a los muros del recinto, y el aspecto tan evolucionado de éstas por la forma de combinar elementos latericios con obra encofrada, podría plantear una cronología cristiana completa para estos dispositivos de flanqueo. Pabón (2016: 226-227) recoge la opinión del anterior autor pero omite juicio de valor alguno. Por otra parte, yerra en la concepción monofásica del recinto y sugiere su erección a la par que los de Écija y Marchena, por semejanzas técnicas, formales y contexto histórico (2016: 256).
}

Branco Correia, F. 2002: "O sistema defensivo da Elvas islamica", Actas do Simpósio Internacional sobre Castelos, Mil anos de Fortificaçoes na Península Ibérica e no Magreb, pp. 357-367. Palmela.

Branco Correia, F. y Picard, C. 1992: "Intervençâo arqueológica no castelo de Juromenha. Primeiros resultados”, Arqueología Medieval, 1, pp. 71-89.

Canivell, J. y Graciani García, A. 2015: "Caracterización constructiva de las fábricas de tapia en las fortificaciones almohades del antiguo Reino de Sevilla", Arqueología de la Arquitectura, 12: e025. https://doi.org/10.3989/ arq.arqt.2015.003

Carriazo Rubio, J. L. y Cuenca López, J M. 2004: Huelva, tierra de castillos. Huelva.

Castillo Armenteros, J. C., Gutiérrez Soler, L. M. y Gutiérrez Calderón, M. V. 2010: "El asentamiento islámico de Giribaile (Jaén). De asentamiento de altura a castillo almohade", Cuadernos de Madīnat al-Zahrā', 7, pp. 239-262.

Cebrián Avellán, A. 2008: "El patrimonio como potencial turístico de las comarcas del Júcar y Cabriel (Albacete)", Papeles de Geografia, 47-48, pp. 35-53.

Córdoba de la Llave, R. 2004: "Fortificaciones almohades de la provincia de Córdoba", en M. Valor, J. L. Villar, y J. Ramírez, Los Almohades. Su patrimonio arquitectónico y arqueológico en el sur de al-Andalus, pp. 123-129. Sevilla.

Córdoba de la Llave, R. y Marfil Ruiz, P. 1995: “Aportaciones al estudio de las murallas medievales de córdoba. Estructura y técnicas de construcción en el sector Ronda del Marrubial", Meridies, 2, pp. 145-177.

Cottart, N. 2012: "La muraille almohade d'Alcácer do Sal. Les graffites", Al-Andalus Magreb, 19, pp. 187-228.

Domínguez Berenjeno, E. L. 2008: "Sevilla y las fortificaciones fluviales del Guadalquivir", $4^{\circ}$ Congreso internacional sobre fortificaciones. Las fortificaciones y el mar, pp. 231-250. Alcalá de Guadaíra.

Eslava Galán, J. 1999: Los castillos de Jaén. Granada.

Ferrer Morales, A. 1996: "Decoración de muros en castillos califales de Andalucía oriental", Atrio, 8-9, pp. 3-18.

García Biosca, J. E. et al. 1998: "La génesis de los espacios urbanos andalusíes (siglos VIII-X): Tortosa, Lleida y Balaguer", en J. Giralt y J. E. García Biosca, El Islam y Cataluña, pp. 136-165. Barcelona-Madrid.

García Fitz, F. 2008: El castillo de Alcalá de Guadaíra (Sevilla). Estudio y fuentes documentales. Sevilla.

García Granados, J. A. 1996: "La primera cerca medieval de Granada. Análisis historiográfico". Arqueología y Territorio Medieval, 3, pp. 91-148.

García Granados, J. A. 2014: "Entre ziríes y almohades. Las fortificaciones urbanas de Granada y su problemática cronológica", en P. Cressier y V. Salvatierra (coords.), Las Navas de Tolosa 1212-2012. Miradas cruzadas, pp. 485-497. Jaén.

Gil-Crespo, I. J. y Maldonado-Ramos, L. 2015: "Hacia una taxonomía constructiva de las tapias de tierra y fábricas encofradas históricas", Informes de la Construcción, 67 (538): e086. https://doi.org/10.3989/ic.14.009

Gilotte, S., Landou, F. y Callède, F. 2013: "Al-Balāț, une ville de gué fluvial (Romangordo, Cáceres): étude préliminaire de son enceinte", Fortificaçoes e Território na Península Ibérica e no Magreb (Séculos VI a XVI), vol. I, pp. 355-367.

Gómez de Terreros Guardiola, M. V. 2010: "La arquitectura de la Orden de Santiago en la provincia de Jaén", La Arquitectura de las Órdenes Militares en Andalucía. Conservación y restauración, vol. 1, pp. 123-237.

Gómez Moreno, M. 1951: "El arte árabe español hasta los almohades", Ars Hispaniae, III, p. 225.

Gómez Muro, R. M. 2003: "Excavación arqueológica de urgencia en la calle Antonio Vico, no 26 y 28", Anuario Arqueológico de Andalucía 2000, vol. 3, tomo 1 , pp. 26-36.

González Rodríguez, R. y Aguilar Moya, L. 2011: El sistema defensivo islámico de Jerez de la Frontera: Fuentes para su reconstrucción virtual. Almería.

Gozalves Cravioto, C. y Gozalves García, H. 2014: "El castillo de las Navas de Tolosa", en P. Cressier y V. Salvatierra (coords.), Las Navas de Tolosa 1212-2012. Miradas cruzadas, pp. 545-550. Jaén.

Graciani García, A. y Tabales Rodríguez, M. A. 2008: "El tapial en el área sevillana. Avance cronotipológico estructural", Arqueología de la Arquitectura, 5, pp. 135-158. 
Gurriarán Daza, P. 2001: “Arquitectura y técnicas constructivas califales en el castillo de Tarifa", Almoraima, 25, pp. 159-180.

Gurriarán Daza, P. 2014: "Las técnicas constructivas en las fortificaciones andalusíes", en F. Sabaté y J. Brufal (eds.), VI Curs Internacional d'Arqueologia Medieval. La ciutat medieval i Arqueologia, pp. 263-292. Pagés Editors, Lérida.

Gurriarán Daza, P. (En prensa): "Madīnat al-Marīya: la Almería nazarí (ss. XIII-XV)", Ciudades nazaries. Estructura urbana, sistema defensivo y suministro de agua.

Gurriarán Daza, P. y Márquez Bueno, S. 2005: "La Almería medieval como fortaleza", en La Alcazaba. Fragmentos para una historia de Almeria, pp. 57-73. Almería.

Gurriarán Daza, P. y Sáez Rodríguez, A. 2002: “Tapial o fábricas encofradas en recintos urbanos andalusíes", Actas del II Congreso Internacional "La Ciudad en al-Andalus y el Magreb”, pp. 561-625. Granada.

Hernández Díaz, J., Sancho Corbacho, A. y Collantes de Terán y Delorme, F. 1951: Catálogo Arqueológico y Artístico de la Provincia de Sevilla. Tomo 3.

Hita Ruiz, J. M. y Villada Paredes, F. 2004: "En torno a las murallas de Ceuta. Reflexiones sobre el amurallamiento de Septem Fratres y la cerca omeya de Sabta", en Actas de las I Jornadas de estudios sobre fortificaciones y memoria arqueológica del hallazgo de la muralla y puerta califal de Ceuta, pp. 17-52. Ceuta.

Hofbauerová, V. y de Antonio Otal, J. M. 2001: “Consolidación y restauración del muro de Alafia. Castillo de Xivert (Castellón)”, Loggia, 11, pp. 74-85.

Hunt, M. A. 2001: "Excavación arqueológica del Castillo de San Jorge (Triana, Sevilla)", Anuario Arqueológico de Andalucía 1998, vol. 3, tomo 2, pp. 811-823.

Ibn Abi Zar. 1964: Rawd al-Qirtas. Valencia. [Traducción de Ambrosio Huici Miranda].

Jiménez Maqueda, D. 1996: “Algunas precisiones cronológicas acerca de las murallas de Sevilla", Laboratorio de Arte, 9, pp. 11-22.

Jiménez Maqueda, D. y Pérez Quesada, P. 2012: "La muralla huérfana. A vueltas con el último recinto amurallado de Madīnat Išbīlia", Romula, 11, pp. 273-347.

Jiménez Maqueda, D. y Pérez Quesada, P. 2015: “El último recinto amurallado de Madīnat Išbīlia. Estado de la cuestión y perspectivas de futuro", Revista Onoba, 3, pp. 51-77.

Jiménez Maqueda, D. y Pérez Quesada, P. 2016: "Las fortificaciones A1mohades de Madīnat Išbülia en el contexto de la arquitectura militar de Al-Andalus", Revista Onoba, 4, pp. 3-39.

Jiménez Martín, A. 2007: "La ciudad almohade y los Caños de Carmona", en La Catedral en la ciudad (III). Los Caños y los difuntos, tomo 1, pp. 21-48.

Landou, F. 2017: "La muralla de al-Balāṭ", en Al-Balāt. Vida y guerra en la frontera de al-Andalus (Romangordo, Cáceres), pp. 27-32. Cáceres.

León Muñoz, A. 2013: "Las fortificaciones de la Córdoba almohade", Fortificaçoes e Território na Península Ibérica e no Magreb (Séculos VI a XVI), vol. I, pp. 337-354.

López Guzmán, R. 1995: "La arquitectura de los almorávides”, La arquitectura del Islam occidental, pp. 107-116. Barcelona-Madrid.

López Martínez, F. J. 1999: "Tapias y tapiales", Loggia, 8, pp. 74-89.

López Osorio, J. M. 2015: La muralla nazari del Albaicín de Granada. Conocimiento y restauración. Tesis doctoral dirigida por Camilla Mileto y Fernando Vargas. Universitat Politècnica de València, València.

Marcos Cobaleda, M. 2015: Los almorávides. Arquitectura de un imperio. Granada.

Márquez Bueno, S. y Gurriarán Daza, P. 2003: "La muralla almohade de Cáceres: aspectos constructivos, formales y funcionales", Arqueología y Territorio Medieval, 10.1, pp. 57-118.

Márquez Bueno, S. y Gurriarán Daza, P. 2006: Cáceres. Una punta de lanza almohade frente a los reinos cristianos. Badajoz.

Márquez Bueno, S. y Gurriarán Daza, P. 2008: "Recursos formales y constructivos en la arquitectura militar almohade de al-Andalus", Arqueología de la Arquitectura, 5, pp. 115-134.

Márquez Bueno, S. y Gurriarán Daza, P. 2011: "Las puertas monumentales en las fortificaciones del occidente andalusí”, I-II Jornadas de Arqueología e Historia Medieval. La marca inferior de al-Andalus, pp. 183-252. Mérida.
Márquez Bueno, S. y Gurriarán Daza, P. 2012: "Tras las huellas de los almohades. Reflexiones sobre las últimas fortificaciones del Badajoz andalusí”, Cuadernos de Arquitectura y Fortificación, 0, pp. 55-76.

Márquez Bueno, S. y Gurriarán Daza, P. 2013: "La restauración de las construcciones almohades. Un recorrido desde su origen hasta la actualidad", Fortificaçoes e Território na Península Ibérica e no Magreb (Séculos VI a XVI), vol. II, pp. 673-681.

Márquez Bueno, S. y Gurriarán Daza, P. 2016: "La coracha almohade de la Torre de los Pozos de Cáceres", Cuadernos de Arquitectura y Fortificación, 3, pp. 55-72.

Márquez Bueno, S. y Gurriarán Daza, P. 2017: "El recinto almohade de Cáceres: nuevas aportaciones", Arqueología y Territorio Medieval, 24, pp. 207-228.

Mileto, C. y Vegas, F. 2010: Documento final de obra de la restauración de la Torre Bofilla. Bétera (Valencia). Memoria inédita. Valencia.

Mileto, C. y Vegas, F. 2011: "La restauración de la torre de la alquería de Bofilla en Bétera (Valencia)", Fortificaciones. Intervenciones en el patrimonio defensivo. Actas del XXXIV Curset. Jornadas Internacionales sobre la intervención en el Patrimonio Arquitectónico, pp. 95-102. Madrid.

Mileto, C. y Vegas, F. 2014: La restauración de la tapia en la Península Ibérica: criterios, técnicas, resultados y perspectivas. Lisboa-Valencia.

Navareño Mateos, A. 1998: Castillos y fortalezas en Extremadura. Murcia.

Navarro Palazón, J. 2012: "El palacio de Onda: un enigma para la historia de Al-Andalus en el siglo XI", en Le plaisir de l'Art du Moyen Âge. Commande, production et réception de l'oeuvre d'art. Mélanges en hommage à Xavier Barral i Altet, pp. 300-312. Paris.

Navarro Palazón, J. y Jiménez Castillo, P. 1995: "El Castillejo de Monteagudo: Qașr Ibn Sacd”, en J. Navarro Palazón (ed.), Casas y palacios de al-Andalus. Siglos XI y XIII, pp. 63-103. Lunwerg Editores, Barcelona-Madrid.

Navarro Palazón, J. y Jiménez Castillo, P. 2011: "Materiales y técnicas constructivas en la Murcia andalusí (siglos X-XIII)", Arqueología de la Arquitectura, 8, pp. 85-120.

Navarro Palazón, J. y Jiménez Castillo, P. 2012: "La arquitectura de Ibn Mardanîsh: revisión y nuevas aportaciones”, en G. M. Borrás Gualis y B. Cabañero Subiza (coords.), La Aljafería y el Arte del Islam Occidental en el siglo XI, pp. 291-350. Zaragoza.

Orihuela Uzal, A. 2013: "Granada, entre ziríes y nazaríes", en Arte y culturas de al-Andalus. El poder de la Alhambra, pp. 47-59. Granada.

Pabón Fernández, M. P. 2016: "Arquitectura defensiva almohade en la provincia de Córdoba. Los ejemplos de Hornachuelos y Palma del Río", Revista Anahgramas, 2, pp. 188-270.

Pascual, J. y Martí, J. 2002: "El recinto fortificado de la Valencia musulmana", Mil anos de Fortificaçoes na Península Ibérica e no Magreb (500-1500). Actas do Simpósio Internacional sobre Castelos, pp. 291-309. Lisboa.

Pavón Maldonado, B. 1993: Ciudades y fortalezas lusomusulmanas. Madrid. Pavón Maldonado, B. 1996: Arquitectura islámica y mudéjar en Huelva y su provincia: prototipos y espacios en la Andalucía occidental. Huelva.

Pavón Maldonado, B. 1999: Tratado de arquitectura hispano-musulmana II. Ciudades y fortalezas. Madrid.

Paz Peralta, J. A. 2015: "Los cubos de las murallas de Zaragoza y del palacio de la Aljafería (1065-1075)", Caesaraugusta, 84, pp. 3-328.

Pérez Macías, J. A. et al. 2000: "Niebla, de Oppidum a Madina", Anales de Arqueología Cordobesa, 11, pp. 91-122.

Pérez Macías, J. A. 2014: "Cerámicas islámicas del Castillo de Gibraleón (Huelva)", Revista Onoba, 2, pp. 207-241.

Pozo Blázquez, F. 2008: Memoria final de la Intervención Arqueológica Puntual en Murallas de la Macarena. Sector Puerta de Córdoba. Documento interno de la Delegación Provincial de la Consejería de Cultura de la Junta de Andalucía, Sevilla.

Pretel Marín, A. 2011: Conquista y doblamiento del Júcar de Albacete. Albacete.

Rabasco García, V. 2015: "El alcázar taifa de Granada: aproximación y problemática en torno al estudio artístico", Estudios Medievales Hispánicos, 4, pp. 57-84.

Sánchez Capote, N. 2013: "Excavación arqueológica y estudio de los trabajos de documentación gráfica, así como lectura de paramentos para 
la adecuación del recinto y exteriores de la alcazaba y la restauración, consolidación y puesta en valor del tramo de Puerta del Alpéndiz a Puerta de Carros, en la Alcazaba de Badajoz", en Extremadura Arqueológica XI, pp. 43 y 89 . Mérida.

Soler Estrela, A. 2009: "La técnica del tapial en las fortificaciones y despoblados de Sharq al-Andalus. Un estudio arquitectónico constructivo", Actas de Sexto Congreso Nacional de Historia de la Construcción, Valencia, 21-24 octubre 2009, pp. 1361-1370. Madrid.

Tabales Rodríguez, M. A. 2002: El Alcázar de Sevilla. Primeros estudios sobre estratigrafia y evolución constructiva. Sevilla.

Tabales Rodríguez, M. A. y Vargas Lorenzo, C. 2014: "La arqueología en el Alcázar de Sevilla. Nuevos estudios en el recinto primitivo e investigaciones derivadas de hallazgos casuales (2012-2014)", Apuntes del Alcázar de Sevilla, 15, pp. 9-59.

Torres Balbás, L. 1941: "La alcazaba almohade de Badajoz", Al-Andalus, VI, 1, pp. 168-203.

Torres Balbás, L. 1948: "Cáceres y su cerca almohade", Al-Andalus, XIII, 2, pp. 446-472.

Torres Balbás, L. 1957: “Arte hispanomusulmán hasta la caída del califato de Córdoba”, en R. Menéndez Pidal (dir.), España musulmana hasta la caída del califato de Córdoba (711-1031). Historia de España, tomo V. Madrid.

Valor Piechotta, M. 2004: "Algunos ejemplos de construcciones defensivas almohades en la provincia de Sevilla", en Los Almohades. Su patrimonio arquitectónico y arqueológico en el sur de al-Andalus, pp. 145-163. Sevilla.

Valor Piechotta, M. 2007: "Algunas ciudades del bajo Guadalquivir entre 1150 y 1260: Carmona, Écija, Niebla y Sevilla”, Al-Ándalus: país de ciudades. Actas del Congreso celebrado en Oropesa (Toledo), pp. 133-176. Madrid.

Valor Piechotta, M. 2008: Sevilla almohade. Málaga.

Valor Piechotta, M. 2009: "La torre de madera del castillo de Constantina (Sevilla)", Historia. Instituciones. Documentos, 36, pp. 419-432.

Villalba Sola, D. 2015: La senda de los almohades: arquitectura y patrimonio. Granada.

Villalba Sola, D. 2016: "El patrimonio arquitectónico almohade en Portugal", Quiroga, 10, pp. 82-94

VV. AA. 2001: Por tierras de la mora encantada. El arte islámico en Portugal. Madrid.

VV. AA. 2002: Arquitectura de al-Andalus. Almería, Granada, Jaén, Málaga. Granada. 